Federal Reserve Bank of Minneapolis

Research Department Staff Report 411

August 2008

\title{
Understanding International Prices: Customers as Capital*
}

\author{
Lukasz A. Drozd \\ University of Wisconsin-Madison \\ Jaromir B. Nosal \\ Columbia University and Federal Reserve Bank of Minneapolis
}

\begin{abstract}
This paper develops a theory of pricing-to-market driven by marketing and bargaining frictions. Our key innovation is a capital theoretic model of marketing in which relations with customers are valuable. In our model, producers search and form long-lasting relations with their customers, and marketing helps overcome the search frictions involved in forming such matches. In the context of international business cycle patterns, the model accounts for observations that are puzzles for a large class of theories: (i) pricing-to-market, (ii) positive correlation of aggregate real export and import prices, (iii) excess volatility of the real exchange rate over the terms of trade, and (iv) low short-run and high long-run price elasticity of international trade flows. The behavior of quantities is shown to be on par with standard international business cycle theories that, in contrast to our model, assume low intrinsic elasticity of substitution between domestic and foreign goods.
\end{abstract}

${ }^{*}$ We thank V.V. Chari, Patrick Kehoe and Fabrizio Perri for valuable advice and encouragement. We are also grateful to Andrew Cassey, Wioletta Dziuda, Borys Grochulski, Ricardo Lagos and Timothy Kehoe for their comments. We also appreciate the comments of the participants of the Minnesota Workshop in Macroeconomic Theory and seminars at the FRB of Minneapolis, Kansas City and Dallas, Federal Reserve Board, University of Wisconsin, Columbia University, University of Pennsylvania, University of Rochester, Georgetown University, University of Virginia, University of Texas, London School of Economics, Ohio State University, SED Meeting in Boston, Midwest Macroeconomic Meetings in Saint Louis, Econometric Society Meetings in Minneapolis and ASSA Meetings in Chicago. All remaining errors are ours. The views expressed herein are those of the authors and not necessarily those of the Federal Reserve Bank of Minneapolis or the Federal Reserve System. 


\section{Introduction}

Standard international macroeconomic models, while being successful in accounting for the business cycle dynamics of quantities, have so far failed to account for the movements of international relative prices. In the data three patterns are evident. First, both real export prices ${ }^{1}$ and real import prices are highly positively correlated, and both are positively correlated with the real exchange rates. Second, the terms of trade is much less volatile than the real exchange rates ${ }^{2}$ Third, there are large and persistent movements in the real exchange rates. These movements, often interpreted as deviations from the law of one price at the aggregate level, are mimicked by persistent deviations from the law of one price at more disaggregated levels.

Neither real business cycle models nor sticky price models have thus far been able to account for these patterns. In the standard real business cycle model, the real export price is negatively correlated with the real import price and the real exchange rate, the terms of trade is more volatile than the real exchange rate, and while real exchange rates are persistent, the law of one price holds at the disaggregated level. While sticky price models can, under certain assumptions, generate some of these features, they fail to generate anywhere near the persistence of real exchange rates observed in the data.$^{3}$

Our reading of the evidence is that it suggests the presence of frictions that inhibit the flow of tradable goods between countries and break the law of one price. This departure

\footnotetext{
${ }^{1}$ Nominal export prices evaluated relative to the domestic price level (measured by the consumer price index $[\mathrm{CPI}]$, the CPI for tradable goods, or the producer price index [PPI]).

${ }^{2}$ Consider the most recent real depreciation 2006-2008. The U.S. real effective exchange depreciated between January 2006 and January 2008 by 11\%, whereas the terms of trade for manufactured goods increased by only $0.5 \%$. Export and import price indices for manufactured articles both increased by $8.7 \%$ and $9.2 \%$, respectively. (Price indices have been pulled out from BLS, and real exchange rate data from IMF IFS Online Database.)

${ }^{3}$ See Chari, Kehoe \& McGrattan (2002).
} 
is supported by the micro-level evidence suggesting that exporters are capable of segmenting the markets and price to the market in which they sell. Marston (1990), Knetter (1993), and Goldberg \& Knetter (1997) provide evidence that when the real exchange rate depreciates, the price of exported goods systematically rises relative to the price of the similar goods sold at home, regardless how fine the level of disaggregation is. The literature has interpreted this result as evidence that markups on exports, measured relative to domestic costs, tend to systematically rise when the real exchange rate depreciates.

Motivated by the above evidence, our paper proposes a theory in which micro founded frictions result in endogenous market segmentation and deviations from the law of one price of the kind suggested by this literature. The key mechanism is that firms need to build market shares, and this process is costly and time consuming. That inhibits the price arbitrage through quantities traded and in the short-run makes real exchange rate fluctuations endogenously lead to pricing-to-market and varying markups on the exported goods. Quantitatively, due to pricing-to-market, our theoretical economy successfully accounts for the volatility of the terms of trade relative to the real exchange rate, and implies a positive correlation between the real export price, the real import price, and the real exchange rate. Business cycle behavior of quantities is on par with the standard IRBC theory.

The idea of sluggish market shares that we pursue here is not entirely new to economics. In fact, such frictions have been considered as a promising avenue since at least the 1980s. Krugman (1986, p. 32), in a seminal contribution to the subject, states:

The best hope of understanding pricing to market seems to come from dynamic models of imperfect competition. At this point, my preferred explanation would stress the roles of [...] the costs of rapidly adjusting the marketing and distribution infrastructure needed to sell some imports, and demand dynamics, resulting from 
the need of firms to invest in reputation.

In addition, such frictions find strong support in the anecdotal evidence about international trade relations between firms and, more recently, in the evidence on firms' market share growth after entry into a foreign market. The anecdotal evidence (H. Hakansson (1982), Turnbull \& M. T. Cunningham (1981), and Egan \& Mody (1992)), based on surveys with the CEOs, pervasively stresses the importance of long-lasting producer-supplier relationships, high switching costs to new suppliers, and highly individualized relationships they have with them. More concrete evidence on firms' market share growth after entry into a foreign market (Ruhl \& Willis (2008)) also supports the view that the buildup of market share takes time. Although dynamic frictions leading to pricing-to-market seemed an attractive avenue for a long time, due to tractability concerns, theoretical treatments of such frameworks are scant. Two notable exceptions are Froot \& Klemperer (1989) and Alessandria (2004). To our best knowledge, our model is the first quantitative exploration of the effects of frictions of this type.

We build on the above general ideas, and develop here a tractable international business cycle model of market share sluggishness with explicitly formulated micro foundations. In addition, to make our model quantitative, we propose a way to put discipline on the new features of the model by bringing in the data on the discrepancy between the low short-run and high long-run estimates of the price elasticity of trade flows. This discrepancy, well documented in the international trade literature, is often referred to as the elasticity puzzle (see Ruhl (2008)). In our framework, the elasticity puzzle is intimately related to the idea of market share sluggishness, which we exploit to calibrate the model and thereby assess its 
quantitative relevance. This appears to be the first attempt to bring this evidence to terms with the Backus, Kehoe \& Kydland (1995) strand of international business cycle literature.$^{4}$

The structure of our model is as follows. First, international trade takes place only through matches between buyers (final good producers) and intermediate good producers. Second, intermediate good producers explicitly build their customer base by choosing spending on a broadly interpreted marketing (market research, design and customization of the product, distribution infrastructure, advertising, technical support). Marketing brings new customers, and each producer, as a state variable, has an endogenous list of customers to whom he can sell a finite quantity of the good. Because it takes time to bring more customers to this list, the producers face what we term a market expansion friction. Due to the bilateral monopoly problem that arises within each match, dock and wholesale prices are determined in the model by bargaining.

Market expansion friction and bargaining are the two key features that give rise to a different behavior of prices in our model. First, bargaining makes prices explicitly depend not only on the marginal cost of production, but also on the valuation of the local buyers (final good producers). In particular, export price explicitly depends on the foreign valuation of the domestic good measured in domestic consumption units. Second, market expansion friction makes the relative supply of domestic to foreign good in each country sluggish, and when combined with a high assumed elasticity of substitution between these goods, results in scant movements of the valuation (retail price) of the domestic good expressed in local consumption units. As a result, when the real exchange rate depreciates in our model, the

\footnotetext{
${ }^{4}$ Other notable contributions to this topic in terms of business cycle models of a different kind are Ruhl (2008) and Ghironi \& Melitz (2005).
} 
foreign valuation of the domestic good expressed in the domestic consumption units goes up almost one-to-one with the real exchange rate, and goes up relative to the valuation of the same good by the domestic buyers. The extra surplus with the foreign buyers created by that is bargained over by the exporters, which leads to an increased markup on the exported good relative to the markup on the same good sold at home. Markup variability leads to a positive correlation of the real export prices with the real import price, and with the real exchange rate. In addition, just like in the data, fluctuations of the real exchange rate on the aggregate level are closely mimicked by the corresponding deviations from the law of one price on the disaggregated levels.

This behavior of prices can be reconciled with the profit-maximizing behavior of the producers in the following way. Unlike standard models, in our model the producers face an additional shadow cost of matching with a marginal customer in a given market. As a result, their marginal cost of selling in a given market comprises not only the marginal cost of producing the good, but also a shadow marginal cost of marketing this good. These additional shadow costs are target market-specific, and when taken into account imply that at all times producers make the same profit on the marginal unit sold at home and abroad.

The main quantitative results of the paper are as follows: (i) relative volatility of the terms of trade to the real exchange rate as low as $26 \%$, (ii) positive correlation of the real export and the real import price, (iii) positive correlation of these prices with the real exchange rate, (iv) low short-run price elasticity of trade flows, and (v) high long-run price elasticity.

In the robustness and sensitivity section, we show that all our results on prices are robust to different modeling assumptions leading to real exchange rate fluctuations. In partic- 
ular, our results are robust to increased volatility of the real exchange rate - a dimension in which all models falls short of the data, including ours. Following Heathcote \& Perri (2004), to address this concern we consider our model under financial autarky, which increases the volatility of the real exchange about four times. We show that all our results still stand 5 . In addition, in the same section we show that an intermediate value of the bargaining power is critical to account for all the facts.

Related literature Dynamic pricing-to-market models with frictions similar to ours are Krugman (1986) and Froot \& Klemperer (1989). In light of these paper, our contribution is to propose a quantitative general equilibrium model in which such frictions endogenously arise from the underlying search and matching frictions. In addition, our paper shows that this view has the potential to reconcile an international macro approach with static trade theory by accounting for the discrepancy between the measured price elasticities of trade.

The most recent quantitative literature on pricing-to-market includes the papers by Alessandria (2005), Atkeson \& Burstein (forthcoming), and Corsetti et al. (2008). The key difference with our paper is that while these authors explore static market structures and static frictions, we explore a conceptually different dynamic friction. For example, in contrast to this literature, in our model permanent shocks do not have permanent effects on prices, and the law of one price is eventually restored. Given the magnitude of the deviations from the law of one price seen in the data, we believe that this property of our model is appealing, as it accords well with the conventional view that arbitrage forces eventually do restore some

\footnotetext{
${ }^{5}$ Under financial autarky, the correlation of the real exchange rate with the consumption ratio is negative, and so our facts are also robust to the Backus-Smith puzzle. The mechanism why this happens is analogous to Corsetti et al. (2008).
} 
form of parity. As Rogoff (1996, p. 647) puts it:

While few empirically literate economists take PPP seriously as a short-term proposition, most instinctively believe in some variant of purchasing power parity as an anchor for long-run real exchange rates.

\section{Three Puzzles for the Standard Model}

In this section, we discuss several regularities of international price dynamics that are a puzzle from the standpoint of the standard international macroeconomic model ${ }^{6}$ In this exercise, we use data for both disaggregated prices and aggregate prices. Our aggregate data is based on H-P-filtered7 quarterly price data for the time period 1980 to 2005, and our sample includes the time series for the following countries: Belgium, Australia, Canada, France, Germany, Italy, Japan, the Netherlands, United Kingdom, United States, Sweden, and Switzerland. Our disaggregated data are based on the disaggregated producer and wholesale pric $\AA^{8}$ data for Japan.

\section{A. Export-Import Price Correlation Puzzle}

One of the central predictions of the standard theory for international relative price movements is that the price of the exported goods, evaluated relative to the overall home price level, moves in the opposite direction to the similarly constructed import price. Intuitively, this implication follows from the fact that, by the law of one price, export prices are tied to the prices of domestically-produced and domestically-sold goods, and import prices are tied to

\footnotetext{
${ }^{6}$ As laid out in Backus, Kehoe \& Kydland (1995), Stockman \& Tesar (1995), Baxter (1995), and Heathcote \& Perri (2002). The critical features are: (i) product differentiation by the country of origin, (ii) law of one price for tradable goods, and (iii) home-bias toward the home tradable good (possibly endogenously induced by the trade barriers).

${ }^{7}$ We explored alternative detrending methods of the data, including the band-pass filter. It does not change any of the results.

${ }^{8}$ Collected from either the producer or wholesaler of these goods.
} 
the same prices abroad expressed in home units. As a result, whenever the real exchange rate depreciates.$^{9}$ import prices rise relative to home prices due to their direct link to the overall foreign price level, and export prices fall relative to home prices, as home prices additionally include the higher priced.

To show the above implication formally, we first derive it from a simple model with only tradable goods and unit elasticity of substitution, and then generalize the results to a model that also includes non-tradable goods.

To this end, we observe that in the Armington model, the overall home price level measured by the CPI can be expressed by a trade-share-weighted geometric average of the prices of the tradable home good $d$, and the tradable foreign good $f$ (the home-bias toward the local good $d$ is parameterized by parameter $1 / 2<\omega<1$ ). Unit elasticity is consistent with the values most commonly used by the researchers ${ }^{10}$. Given the formula for the CPI, the definitions of the real export price $p_{x}$ and the real import price $p_{m}$ of a country (deflated by CPI) can be expressed as follows:

$$
\begin{aligned}
p_{x} & =\frac{P_{d}}{C P I}=\frac{P_{d}}{P_{d}^{\omega} P_{f}^{1-\omega}}=\left(\frac{P_{d}}{P_{f}}\right)^{(1-\omega)}, \\
p_{m} & =\frac{P_{f}}{C P I}=\frac{P_{f}}{P_{d}^{\omega} P_{f}^{1-\omega}}=\left(\frac{P_{f}}{P_{d}}\right)^{\omega} .
\end{aligned}
$$

From the above formulas, observe that according to the model the correlation between $p_{x}$ and $p_{m}$ must necessarily be negative.

\footnotetext{
${ }^{9} \mathrm{An}$ increase in the foreign overall price level relative to the overall home price level.

${ }^{10}$ For example, Heathcote \& Perri (2002) use elasticity of substitution between home and foreign goods equal to 0.9, and Backus, Kehoe \& Kydland (1995) assume 1.5. These small departures from unity do not matter quantitatively for what follows.
} 
To contrast this prediction with the data, we calculate export and import price indices from the import and export price deflators ${ }^{11}$ and then deflate these prices by the all-items CPI index to construct $p_{x}$ and $p_{m}$, respectively ${ }^{12}$, Figure 1 and Table 1 report the results. As we can see, the correlations between real export and import prices are highly positive across all 12 OECD countries in our sample, and the values often exceed 0.9. (These prices are also quite volatile. Their median volatility relative to the real exchange rate is 0.56 for the real export price and 0.83 for the real import price, respectively.)

In the last step, we verify whether the above results are also true in a model that explicitly incorporates non-tradable goods. In order to do this, we use a more general constant elasticity of substitution (CES) aggregator,

$$
C P I=\left(v\left(P_{d}^{\omega} P_{f}^{1-\omega}\right)^{\frac{\mu-1}{\mu}}+(1-v) P_{N}^{\frac{\mu-1}{\mu}}\right)^{\frac{\mu}{\mu-1}}
$$

because the elasticity $\mu$ most commonly used in the literature between tradable and nontradable goods is significantly below unity ${ }^{13}$

Straightforward algebraic manipulation applied to the definitions of $p_{x}$ and $p_{m}$ with the above formula for the CPI imply that, according to the model with non-tradable goods,

\footnotetext{
${ }^{11}$ Constructed from the time series for constant- and current-price import and export prices at the national level.

${ }^{12}$ Formal definitions are stated in the Appendix.

${ }^{13}$ For example, Corsetti et al. (2008) follow Mendoza (1991) and use the elasticity of substitution between tradable and non-tradable goods equal to 0.76, but Stockman \& Tesar (1995) report a value as low as 0.44. The share of non-tradable goods $v$ in the consumer basket oscillates around $50-60 \%$.
} 
the following two objects must be negatively correlated:

$$
\begin{aligned}
& p_{m}^{T} \equiv\left[\frac{1}{v}\left(\frac{P_{f}}{P}\right)^{\frac{1-\mu}{\mu}}-\frac{(1-v)}{v}\left(\frac{P_{f}}{P_{N}}\right)^{\frac{1-\mu}{\mu}}\right]^{\frac{\mu}{1-\mu}}=\left(\frac{P_{f}}{P_{d}}\right)^{\omega}, \\
& p_{x}^{T} \equiv\left[\frac{1}{v}\left(\frac{P_{d}}{P}\right)^{\frac{1-\mu}{\mu}}-\frac{(1-v)}{v}\left(\frac{P_{d}}{P_{N}}\right)^{\frac{1-\mu}{\mu}}\right]^{\frac{\mu}{1-\mu}}=\left(\frac{P_{d}}{P_{f}}\right)^{(1-\omega)} .
\end{aligned}
$$

To contrast the above prediction with the data, we approximate the price of nontradable goods $P_{N}$ by the CPI for housing and services, and similarly as before use all-items CPI to measure $P$, and export (import) price deflators to measure $P_{d}\left(P_{f}\right)$. To generate the time series for $p_{m}^{T}, p_{x}^{T}$, we first detrend the time series for $P_{d} / P, P_{d} / P_{N}$ (same for $P_{f}$ ) and normalize them so that they oscillate around unity. The parameters $\mu$ and $v$ are assumed to be in the range of estimates from the literature that are least favorable to positive correlation $(v=.6$ is taken from Corsetti et al. (2008) and $\mu=0.44$ from Stockman \& Tesar (1995)). The results are reported in the last three columns of Table 1. As one can see, the previously reported correlations remain almost intact (for the included set of countries). The reason behind this result is a high positive correlation and similar volatility of the two objects, $P_{d} / P$ and $P_{d} / P_{N}$ (same for $P_{f}$ ), which are subtracted in the formula for $p_{x}^{T}$. The median correlation coefficient between them is as high as 0.98 . Now, because $1 / v \approx 2$ and $(1-v) / v \approx 1$, not surprisingly the properties of the time series for $p_{x}^{T}$ and $p_{m}^{T}$ are similar to $p_{x}$ and $p_{m}$. Thus, we conclude that non-tradable goods cannot account for the export-import price correlation puzzle. 


\section{B. Terms of Trade Relative Volatility Puzzle}

The second firm prediction of the standard theory is about the excess volatility of the

terms of trade $p=\frac{P_{f}}{P_{d}}$ (price of imports in terms of exports) relative to the real exchange $x$. In this respect, the standard theory predicts that the terms of trade should be exactly equal to the $P P I$-based real exchange rate ${ }^{14}$ and thus exactly as volatile. The reason is that, by the law of one price, the price index of exported goods is equal to the home producer price index and the price index of the imported goods is equal to the foreign country producer price index measured in the home numeraire units. In contrast, in the data export and import prices are highly positively correlated and the terms of trade - defined as their ratio-turns out to be not that much volatile relative to real exchange rate. In particular, its volatility is significantly smaller than the volatility of the CPI or PPI based real exchange rates. This property of the data is illustrated in Figure 2 for the US, and is more broadly analyzed in Table $2[15$

\section{Pricing-to-Market Puzzle}

In addition to the aggregate anomalies shown above, there is pervasive direct evidence in the disaggregated price data against the law of one price. More precisely, the law of one price is systematically violated across countries regardless of how fine the level of disaggregation is ${ }^{16}$ Here we document this feature of the data using a sample of the disaggregated price data from the Japanese manufacturing industry. The reason why Japan is an excellent

\footnotetext{
${ }^{14}$ The PPI-based real exchange rate is the foreign producer price index relative to the home producer price index, when both measured in common numeraire.

${ }^{15}$ When the import price data is cleaned from the influence of the highly volatile crude oil prices - which we do later - the relative volatility of the terms of trade relative to the real exchange rate falls further to about $1 / 3$.

${ }^{16}$ Our analysis here will be reminiscent of the incomplete pass-through literature that documents related facts using regression analysis. For example, similar analysis can be found in Marston (1990).
} 
case to look up what happens behind the scene is twofold. First, aggregate prices exhibit very strong patterns in this country - all correlations are close to unity. Second, Japanese national statistics report the producer/wholesale prices of domestically produced and sold goods - making this dataset particularly suitable for the kind of exercise we consider here. (Standard PPI or WPI [wholesale price index] series would mix in export prices or import prices, respectively.)

Our dataset includes quarterly time series for producer/wholesale level price indices for 31 highly disaggregated and highly traded manufactured commodity classifications. For each commodity classification, we combine information on the export price (EPI) and the domestic wholesale/producer price (DPI) for the same good, which, as mentioned above, includes only the prices of domestically-produced and domestically-sold goods. All these price indices come from the exporter/producer survey ${ }^{17}$ and include 31 commodity classifications, which together account for $59 \%$ of the total value of Japanese exports and $18 \%$ of the total value of domestic shipments (as of year 2000). To give a better feel for the level of disaggregation, the examples of commodity classifications would include: copying machines, computers, agricultural tractors, ball bearings, small passenger cars, and so on 18

To characterize the key property of the disaggregated price data, and also emphasize the analogy to our aggregate analysis, we construct here the analogous objects to the aggregate real export price indices considered before, but instead computed separately for each single commodity classification that is in our sample. More specifically, we divide the export price index (EPI) of each commodity $i$ by the overall Japanese CPI and use the following

\footnotetext{
${ }^{17}$ The non-tradable content of the price is thus minimal.

${ }^{18}$ The complete list of commodity categories included can be found in the technical appendix available online at http://www.ssc.wisc.edu/ldrozd/my_files/Appendix1.pdf.
} 
identity relation:

$$
p_{x}^{i} \equiv \frac{E P I_{i}}{D P I_{i}} \frac{D P I_{i}}{C P I}
$$

to decompose the fluctuations of the real export price of each commodity into two distinct components: (i) the pricing-to-market term $\frac{E P I_{i}}{D P I_{i}}$ - capturing the deviations of the export price of the given commodity from its corresponding home price - and (ii) the residual term $\frac{D P I_{i}}{C P I}$ - capturing the deviations of the home price of commodity $i$ from the overall consumer price index. With this decomposition in hand, we next look at the contribution of each term to the overall fluctuations of the real export price of commodity $i$.

Clearly, under the law of one price, we should expect that the first term $\frac{E P I_{i}}{D P I_{i}}$ should be almost constant, and all the variation in the real export prices $p_{x}^{i}$ should come from the fluctuations of the residual term $\frac{D P I_{i}}{C P I}$. The puzzle is that the exact opposite pattern is in the data. First, most of the variance of the export prices $p_{x}^{i}$ is driven by the pricing-to-market term. Second, the pricing-to-market term goes up and down with the real exchange rate. Below, we provide a detailed statistical analysis of these two properties.

Variance comes from pricing-to-market term The two terms, the pricing-to-market term and the residual term, covary negatively in the data. Hence, we can focus solely on the contribution of the variance of each term to the overall variance of the import price indextelling us the importance of each of the terms in generating the overall volatility. Using variance decomposition,

$$
\operatorname{median}\left(\frac{\operatorname{var}\left(\frac{E P I_{i}}{D P I_{i}}\right)}{\operatorname{var}\left(\frac{E P I_{i}}{D P I_{i}}\right)+\operatorname{var}\left(\frac{D P I_{i}}{C P I}\right)}\right),
$$


the pricing-to-market term $\frac{E P I_{i}}{D P I_{i}}$ carries about $93 \%$ of the total volatility, and the residual term $\frac{D P I_{i}}{C P I}$ carries only $7 \%$, where $\operatorname{var}(\cdot)$ in the formula above refers to the logged and H-P-filtered quarterly time series (with a smoothing parameter $\lambda=1600$ ).

Pricing-to-market term varies systematically with the real exchange rate In addition, the pricing-to-market term $\frac{E P I_{i}}{D P I_{i}}$ turns out to be highly positively correlated with the Japanese real (and nominal) exchange rate - possibly suggesting the missing element of the theory to account for the aggregate price data. The median correlation of $\frac{E P I_{i}}{D P I_{i}}$ with the Japanese real exchange rate is 0.84 (and 0.78 with the nominal exchange rate). In contrast, the median correlation of the residual term $\frac{D P I_{i}}{C P I}$ with the real exchange rate is even slightly negative and equal to $-0.15 \sqrt{19}$ As a result, given the high volatility of the first term, the median relative volatility of $p_{x}^{i}$ to the real exchange rate is as high as $88 \%$, and the median correlation of $p_{x}^{i}$ with the real exchange rate is as high as 0.82 . Having established basic properties of the international relative price data, we now turn to the presentation of our model.

\section{Model Economy}

Time is discrete, $t=0,1,2, \ldots, \infty$. There are two ex-ante symmetric countries labeled domestic and foreign. Each country is populated by a large number of identical and infinitely lived households. Households supply labor and physical capital to producers, consume goods, trade assets, and accumulate physical capital. Producers combine labor and physical capital supplied by households and produce country-specific tradable goods. The tradable good produced in the domestic country is labeled $d$, and the tradable good produced in the foreign

\footnotetext{
${ }^{19}$ We find a similar negative correlation with the nominal exchange rate.
} 
country is labeled $f$.

In addition, in each country there is a sector of retailers who purchase goods from domestic and foreign producers and resell them to the households in a local competitive retail market. Retailers search for the producers of goods (domestic and foreign importers), and producers accumulate marketing capital to attract the searching retailers. These retailers play the role of intermediaries in trade between households and producers and allow us to model the key frictions this paper focuses on 20

Following the standard international real business cycle framework by Backus, Kehoe \& Kydland (1995), the source of uncertainty in this economy is a random productivity shock affecting the production technology of each country. The history of shocks up to and including period $t$ is denoted by $s^{t}=\left(s_{0}, s_{1}, \ldots, s_{t}\right)$. The initial realization $s_{0}$, as well as the time invariant probability measure $\mu$ over the compact shock space $S$, are given. In the presentation of the model, we will often exploit symmetry and present it from the domestic country's perspective only. To distinguish foreign country-related variables from the domestic ones, we use an asterisk.

\section{A. Production Technology}

Each country is assumed to have access to a constant returns to scale production function $z F(k, l)$ that uses country-specific capital $k$ and labor $l$, and is subject to a country-

\footnotetext{
${ }^{20}$ There is an equivalent formulation that incorporates this sector directly into the household. We choose this way and the label for the sake of clarity. The retailers should not be interpreted literally as restricted to the retail sector - these are any other producers who participate in the overall production process.
} 
specific technology shock $\hat{z} \equiv \log (z)$ following an exogenous $\operatorname{AR}(1)$ process

$$
\begin{aligned}
\hat{z}\left(s^{t}\right) & =\psi \hat{z}\left(s^{t-1}\right)+\varepsilon_{t}, \\
\hat{z}^{*}\left(s^{t}\right) & =\psi \hat{z}^{*}\left(s^{t-1}\right)+\varepsilon_{t}^{*},
\end{aligned}
$$

where $0<\psi<1$ is a common persistence parameter, and $s_{t} \equiv\left(\varepsilon_{t}, \varepsilon_{t}^{*}\right) \in S$ is an i.i.d. normally distributed random variable with zero mean.

Since the production function is assumed to be constant returns to scale, we summarize the production process by an economy-wide marginal cost $v$. Given domestic factor prices $w$, $r$ and domestic shock $z$, the marginal cost in the domestic country is given by the following unit cost minimization problem:

$$
v\left(s^{t}\right) \equiv \min _{k, l}\left\{w\left(s^{t}\right) l+r\left(s^{t}\right) k \mid z\left(s^{t}\right) F(k, l)=1\right\} .
$$

\section{B. Households}

The problem of the household is standard and identical to a decentralized version of the standard model under complete asset markets.

Each country is populated by a unit measure of identical and infinitely lived households. Households supply production factors to domestic producers, accumulate physical capital, and consume goods. After each history $s^{t}$, the stand-in household chooses the allocation, which consists of the level of consumption $c$, investment in physical capital $i$, labor supply $l$, purchases of tradable goods $d, f$, and purchases of a set of one-period $s_{t+1^{-}}$contin- 
gent bonds $b\left(s_{t+1} \mid s^{t}\right)$ to maximize the expected discounted lifetime utility

$$
\sum_{t=0}^{\infty} \beta^{t} \int_{S^{t}} u\left(c\left(s^{t}\right), l\left(s^{t}\right)\right) \mu\left(d s^{t}\right) .
$$

The preferences toward the domestic and foreign goods are modeled by the Armington aggregator $G(d, f)$ with an assumed exogenous elasticity of substitution (Armington elasticity) $\gamma$ and a home-bias parameter $\omega$,

$$
G(d, f)=\left(\omega d^{\frac{\gamma-1}{\gamma}}+(1-\omega) f^{\frac{\gamma-1}{\gamma}}\right)^{\frac{\gamma}{\gamma-1}}, \gamma \geq 0, \omega>1 / 2
$$

Households combine goods $d$ and $f$ through the above aggregator into a composite good, which they use for consumption and investment purposes

$$
c\left(s^{t}\right)+i\left(s^{t}\right)=G\left(d\left(s^{t}\right), f\left(s^{t}\right)\right) .
$$

Investment is used to accumulate physical capital $k$, which is subject to a constant exogenous depreciation rate $\delta$

$$
k\left(s^{t}\right)=(1-\delta) k\left(s^{t-1}\right)+i\left(s^{t}\right), 0<\delta \leq 1 .
$$

Asset markets are complete, and the budget constraint of the domestic household is given by

$$
\begin{aligned}
& P_{d}\left(s^{t}\right) d\left(s^{t}\right)+P_{f}\left(s^{t}\right) f\left(s^{t}\right)+\int_{S} Q\left(s_{t+1} \mid s^{t}\right) b\left(s_{t+1} \mid s^{t}\right) \mu\left(d s_{t+1}\right) \\
= & b\left(s^{t}\right)+w\left(s^{t}\right) l\left(s^{t}\right)+r\left(s^{t}\right) k\left(s^{t-1}\right)+\Pi\left(s^{t}\right), \text { all } s^{t}
\end{aligned}
$$


and of the foreign household by

$$
\begin{aligned}
& P_{d}^{*}\left(s^{t}\right) d^{*}\left(s^{t}\right)+P_{f}^{*}\left(s^{t}\right) f^{*}\left(s^{t}\right)+\int_{S} \frac{x\left(s^{t+1}\right)}{x\left(s^{t}\right)} Q\left(s_{t+1} \mid s^{t}\right) b^{*}\left(s_{t+1} \mid s^{t}\right) \mu\left(d s_{t+1}\right) \\
= & b^{*}\left(s^{t}\right)+w^{*}\left(s^{t}\right) l^{*}\left(s^{t}\right)+r^{*}\left(s^{t}\right) k^{*}\left(s^{t-1}\right)+\Pi^{*}\left(s^{t}\right), \text { all } s^{t} .
\end{aligned}
$$

In the above formulation of the budget constraints, we assume that the composite consumption good is the numeraire of each country ( $c$ in domestic country, $c^{*}$ in the foreign). We do so by normalizing the level of prices in each country so that the CPI price index of this country is equal to 1 . The CPI is defined by the lowest cost of acquiring a unit of composite consumption ( $c$ in the domestic country, $c^{*}$ in the foreign country), and in the case of the domestic country it solves to

$$
C P I=\left(P_{d}^{1-\gamma} \omega^{\gamma}+P_{f}^{1-\gamma}(1-\omega)^{\gamma}\right)^{\frac{1}{1-\gamma}}
$$

The budget constraints include (from the left-hand side): (i) purchases of domestic goods, (ii) purchases of foreign goods, (iii) purchases of one-period forward $s_{t+1}$ - state contingent bonds, (iv) income from maturing bonds purchased at history $s^{t-1}$, (v) labor income, (vi) rental income from physical capital, and (vii) the dividends paid out by home firms. In addition, the foreign budget constraint, due to a different numeraire unit, involves an additional price $x\left(s^{t}\right)$ that translates the foreign numeraire to the domestic numeraire in the term

$$
\int_{S} \frac{x\left(s^{t+1}\right)}{x\left(s^{t}\right)} Q\left(s_{t+1} \mid s^{t}\right) b^{*}\left(s_{t+1} \mid s^{t}\right) .
$$


By definition of the numeraires, this price is the real exchange rate ${ }^{21} x$, which integrates the domestic and the foreign asset market into one world asset market. Since the foreign budget constraint is expressed in the foreign country numeraire, and so is $b^{*}$, in order to use $\mathrm{Q}$ as the intertemporal price, the term $x\left(s^{t+1}\right) b^{*}\left(s_{t+1} \mid s^{t}\right)$ first translates the purchase value of the foreign bonds to the domestic country numeraire units, and then $Q\left(s_{t+1} \mid s^{t}\right) / x\left(s^{t}\right)$ expresses the price of this purchase again in terms of the foreign numeraire.

Summarizing, given the initial values for $k\left(s^{-1}\right)$ and $b\left(s^{-1}\right)=0$, households choose their allocations to maximize (8) subject to the aggregation constraint (10), the law of motion for physical capital (11), the budget constraint (12), the standard no-Ponzi scheme condition, and the numeraire normalization. The first order conditions are:

(i) demand equations

$$
\begin{aligned}
& P_{d}\left(s^{t}\right)=G_{d}\left(s^{t}\right), \\
& P_{f}\left(s^{t}\right)=G_{f}\left(s^{t}\right),
\end{aligned}
$$

(ii) labor/leisure choice

$$
\frac{u_{l}\left(s^{t}\right)}{u_{c}\left(s^{t}\right)}=-w\left(s^{t}\right)
$$

(iii) Euler equation

$$
u_{c}\left(s^{t}\right)=\beta E_{s^{t}}\left[u_{c}\left(s^{t+1}\right)\left(\left(1-\delta_{k}\right)+r\left(s^{t+1}\right)\right)\right]
$$

\footnotetext{
${ }^{21}$ The price of the foreign composite consumption good $c^{*}$ in terms of the domestic composite consumption good $c$ by the numeraire assumption given above.
} 
(iv) pricing kernels (includes foreign household condition)

$$
\begin{aligned}
Q\left(s_{t+1} \mid s^{t}\right) & =\beta \frac{u_{c}\left(s^{t+1}\right)}{u_{c}\left(s^{t}\right)}, \\
\frac{x\left(s^{t+1}\right)}{x\left(s^{t}\right)} Q\left(s_{t+1} \mid s^{t}\right) & =\beta \frac{u_{c}^{*}\left(s^{t+1}\right)}{u_{c}^{*}\left(s^{t}\right)},
\end{aligned}
$$

where $u_{l}\left(s^{t}\right), u_{c}\left(s^{t}\right), G_{d}\left(s^{t}\right), G_{f}\left(s^{t}\right)$ denote derivatives of the instantaneous utility function and the Armington aggregator function with respect to the subscript arguments.

Comparing condition (iv) for the domestic country and the foreign country, and iterating backward to state $s^{0}$, it is straightforward to show that under ex-ante symmetry we obtain

$$
x\left(s^{t}\right)=\frac{u_{c}^{*}\left(s^{t}\right)}{u_{c}\left(s^{t}\right)} .
$$

The above equation is the efficient risk sharing condition. It says that, under efficient risk sharing, marginal utility from consumption across countries must align with the relative price of consumption. To a first approximation, this condition implies that a country consumes more in a given state and date if and only if its consumption costs less in that state and date.

It is instructive to note that the above condition is implied solely by the frictionless financial structure of the model. Since it is the well-documented source of the failure of the models to account for the properties of the real exchange rates in the data, we will later examine whether our results are robust to modifications that would result in different properties of the real exchange rate than the ones implied by the efficient risk sharing condition. 


\section{Producers}

Tradable goods $d$ and $f$ are country specific and are produced by a unit measure of atomless competitive producers residing in each country. Producers employ local capital and labor to produce these goods using the technology specific to their country of residence. The unit production cost is given by (7).

Endogenous list of customers The novel feature introduced in this paper is that producers match with the retailers in order to sell their goods. Specifically, the producers have access to an explicitly formulated marketing technology and accumulate what we term marketing capital $m$. Marketing capital must be separately accumulated in each country. The relative marketing capital accumulated by a given producer to marketing capital held by other producers determines the fraction of the searching retailers that match with this producer in a given country. More specifically, an exporter from the domestic country with marketing capital $m_{d}^{*}\left(s^{t}\right)$ in the foreign country attracts a fraction

$$
\frac{m_{d}^{*}\left(s^{t}\right)}{\bar{m}_{d}^{*}\left(s^{t}\right)+\bar{m}_{f}^{*}\left(s^{t}\right)}
$$

of the searching retailers from this country, where $\bar{m}_{d}^{*}\left(s^{t}\right)$ denotes the average level of marketing capital held by the $f$ and $d$ good producer in the foreign country.

The shares given by 21 play a critical role in the customer capital buildup problem faced by the producers in this environment because they determine the arrival rate of the new customers to the endogenous list of customers $H\left(s^{t}\right)$ a given producer has. More specifically, given the measure $h\left(s^{t}\right)$ of searching retailers in a given country, who are potential customers, 
the arrival of new customers to the list of a given producer is

$$
\frac{m_{d}\left(s^{t}\right)}{\bar{m}_{d}\left(s^{t}\right)+\bar{m}_{f}\left(s^{t}\right)} h\left(s^{t}\right) .
$$

Since each contact (match) with a retailer is long-lasting and is subject to an exogenous destruction rate $\delta_{h}$, the evolution of the endogenous list of customers $H_{d}\left(s^{t}\right)$ is compactly described by the following law of motion:

$$
H_{d}\left(s^{t}\right)=\left(1-\delta_{H}\right) H_{d}\left(s^{t-1}\right)+\frac{m_{d}\left(s^{t}\right)}{\bar{m}_{d}\left(s^{t}\right)+\bar{m}_{f}\left(s^{t}\right)} h\left(s^{t}\right) .
$$

The size of this list is critical for the producer, as it determines the amount of goods this producer can sell in a given market (country). More specifically, here we assume that in each match, one unit of the good can be traded per period. ${ }^{22}$ Thus, sales of a given producer cannot exceed the size of the customer list $H$. For example, the sales constraint of a producer of good $d$ in the foreign country with a customer list $H_{d}^{*}$ would be given by

$$
d^{*}\left(s^{t}\right) \leq H_{d}^{*}\left(s^{t}\right)
$$

Marketing capital In order to attract the searching customers, producers in the model accumulate marketing capital $m$. Given last period's level of marketing capital $m_{d}\left(s^{t-1}\right)$ and the current level of instantaneous marketing input $a_{d}\left(s^{t}\right)$, current period marketing capital

\footnotetext{
${ }^{22}$ Clearly, a parameterized formulation using a continuous notion of the capacity constraint on a match level would be possible. Since these capacity constraints are the main point of this work, we choose to focus on this more straightforward formulation of the key friction.

${ }^{23}$ Due to always positive markups, this condition binds in our model (on the simulation path).
} 
$m_{d}\left(s^{t}\right)$ is given by

$$
m_{d}\left(s^{t}\right)=\left(1-\delta_{m}\right) m_{d}\left(s^{t-1}\right)+a_{d}\left(s^{t}\right)-\phi m_{d}\left(s^{t-1}\right)\left(\frac{a_{d}\left(s^{t}\right)}{m_{d}\left(s^{t-1}\right)}-\delta_{m}\right)^{2} .
$$

Note that the above specification nests two key features: (i) the decreasing returns from the instantaneous marketing input $a_{d}\left(s^{t}\right)$ and (ii) the capital-theoretic specification of marketing. Both features, parameterized by the market expansion friction parameter $\phi$ and depreciation rate $\delta_{m}$, are intended to capture the idea that marketing-related assets like brand awareness, reputation or distribution network are capital for a firm and the buildup of these assets takes time. As we will later show, this feature gives rise to the disconnect between the short-run and the long-run price elasticity of trade flows in response to price fluctuations. We will refer to this feature as a market expansion friction.

Profit maximization Producers sell goods in the domestic country for the wholesale prices $p_{d}$ and in the foreign country for the wholesale export price $p_{x} \equiv x p_{d}^{*}$ when measured in domestic numeraire. These prices are determined by bargaining with the domestic and foreign retailers. The details of the bargaining problem are described in the next section. Here, we note that since at every contingency $s^{t}$ the producer can perfectly anticipate the outcome of bargaining and cannot strategically influence it beforehand, in the profit maximization problem we can effectively treat these prices as if they were given.

The instantaneous profit function $\Pi$ of the producer is determined by the difference between the profit from sales in each market and the total cost of marketing these goods, and 
it can be summarized by the following expression:

$$
\Pi=\left(p_{d}-v\right) d+\left(x p_{d}^{*}-v\right) d^{*}-v a_{d}-x v^{*} a_{d}^{*}
$$

Given the instantaneous profit function $\Pi$, our representative producer from the domestic country, who enters period $t$ in state $s^{t}$ with the customer list

$$
H_{d}\left(s^{t-1}\right), H_{d}^{*}\left(s^{t-1}\right)
$$

and marketing capital

$$
m_{d}\left(s^{t-1}\right), m_{d}^{*}\left(s^{t-1}\right)
$$

chooses the allocation

$$
a_{d}\left(s^{t}\right), a_{d}^{*}\left(s^{t}\right), m_{d}\left(s^{t}\right), m_{d}^{*}\left(s^{t}\right), d\left(s^{t}\right), d^{*}\left(s^{t}\right), H_{d}\left(s^{t}\right), H_{d}^{*}\left(s^{t}\right)
$$

to maximize the present discounted stream of future profits given by

$$
\max \sum_{\tau=t}^{\infty} \int Q\left(s^{\tau}\right) \Pi\left(s^{\tau}\right) \mu\left(d s^{\tau} \mid s^{t}\right)
$$

subject to the marketing technology constraints (25), sales constraints $(24)$, and the laws of motion for customer lists 23 . The discount factor $Q\left(s^{t}\right)$ is defined by the recursion

$$
Q\left(s^{t}\right)=Q\left(s_{t} \mid s^{t-1}\right) Q\left(s^{t-1}\right)
$$


where $Q\left(s_{t} \mid s^{t-1}\right)$ denotes the conditional pricing kernel given by (19).

\section{Retailers}

In each country there is a sector of atomless retailers who purchase goods from producers and resell them in a local competitive market to households. It is assumed that the new retailers who enter into the sector must incur the initial search cost $\chi v$ in order to find a producer with whom they can match and trade. Each match lasts until it exogenously dissolves with a per-period probability $\delta_{h}$. Until the match lasts, the producer and the retailer hold an option to trade one unit of the good per period. In equilibrium, the industry dynamics is governed by a free entry and exit condition, which endogenously determines the measure $h$ of new entrants (searching retailers). Trade between households and retailers takes place in a local competitive market at prices $P_{d}$ for good $d$ and $P_{f}$ for good $f$. In equilibrium, these prices are given by (16), and throughout the rest of this paper we refer to them as retail prices (in contrast to the wholesale prices $p_{d}, p_{f}$ ).

In each period, there is a mass of retailers already matched with the producers $H$ and a mass of new entrants $h$ (searching retailers). A new entrant, upon paying the up-front search $\operatorname{cost} \chi v$, meets with probability $\pi$ a producer from the domestic country and with probability $1-\pi$ the producer from the foreign country (selling in the domestic country). The entrant takes this probability as given, but in equilibrium it is determined by the marketing capital levels accumulated by the producers, according to

$$
\pi\left(s^{t}\right)=\frac{\bar{m}_{d}\left(s^{t}\right)}{\bar{m}_{d}\left(s^{t}\right)+\bar{m}_{f}\left(s^{t}\right)} .
$$


The measures of already matched retailers $H$ endogenously evolve in each country in consistency with 23 .

Finally, we should stress that we call these agents retailers to clearly distinguish them from other producers. But in fact, we think of them as producers that participate in the process of bringing the good from the production site to the final consumer ${ }^{24}$

We next proceed with the discussion of the bargaining problem between the producer and the retailer, and at the end of this section, we set up the zero profit condition governing the entry of new retailers $h$ (search intensity).

Bargaining and wholesale prices An important feature of the environment is how wholesale prices are determined. In this respect, we depart from the competitive paradigm and assume that in each period, after matching takes place, each retailer bargains with the producer over the total future surplus from a given match. We assume that this surplus is split in consistency with Nash bargaining solution with continual renegotiation.

To set the stage for the bargaining problem, we first need to define the value function from the match for the producer and for the retailer. We assume that they trade at history $s^{t}$ at some arbitrary wholesale price $p$, and in the future they will trade according to an equilibrium price schedule $p\left(s^{t}\right)$. For the foreign producer selling in the domestic country (importer), these value functions (measured in domestic country numeraire) are given by

$$
W_{f}\left(p ; s^{t}\right)=\max \left\{0, p-x\left(s^{t}\right) v^{*}\left(s^{t}\right)\right\}+\left(1-\delta_{h}\right) E_{t} Q\left(s_{t+1} \mid s^{t}\right) W_{f}\left(p_{f}\left(s^{t+1}\right) ; s^{t+1}\right),
$$

\footnotetext{
${ }^{24}$ The distribution of the added value could be modified accordingly, and it would not change the results of the paper.
} 
and for the domestic retailer matched with the foreign producer by

$$
J_{f}\left(p ; s^{t}\right)=\max \left\{0, P_{f}\left(s^{t}\right)-p\right\}+\left(1-\delta_{h}\right) E_{t} Q\left(s_{t+1} \mid s^{t}\right) J_{f}\left(p_{f}\left(s^{t+1}\right) ; s^{t+1}\right) .
$$

The flow part of the above Bellman equations for the producer is determined by the difference between the wholesale price of the good $p$ and the cost of producing this good given by $x v^{*}$, whereas for the retailer, it is determined by the difference between the retail price (resell price) of the good $P_{f}$ and the wholesale price paid to the producer $p$.

Given the above expected present discounted values from a match, we are now ready to set up the bargaining problem, which imposes the following restriction on the equilibrium schedule of the wholesale prices $p\left(s^{t}\right)$

$$
p_{f}\left(s^{t}\right) \in \arg \max _{p}\left\{J_{f}\left(p ; s^{t}\right)^{\theta} W_{f}\left(p ; s^{t}\right)^{1-\theta}\right\}, \text { all } s^{t},
$$

where $\theta$ denotes the bargaining power of a producer 25 . Other prices are defined by analogy.

The following proposition additionally establishes that with continual renegotiation at every date and state $s^{t}$, the pricing formulas resulting from the above bargaining problem simply allocate $\theta$ fraction of the total (static) instantaneous trade surplus given by $P_{f}-x v^{*}$ to the producer and $1-\theta$ to the retailer.

Proposition 1. Assume that trade takes place at $s^{t}$. The solution to the bargaining problem stated in (31) is given by

\footnotetext{
${ }^{25}$ Note that the search cost and the marketing cost are sunk from the perspective of any given match and cannot be used to form another match in the same period, which means that the outside options of both sides in the bargaining problem are zero.
} 


$$
p_{f}\left(s^{t}\right)=\theta P_{f}\left(s^{t}\right)+(1-\theta) x\left(s^{t}\right) v^{*}\left(s^{t}\right)
$$

Proof. See the Appendix.

The intuition behind this result is as follows. Given the continual renegotiation of the price, Nash bargaining implies that in every period the total present discounted value from the match $S$ is split in proportion $\theta, 1-\theta$ between the producer and the retailer. In particular, from today on this is the case, and for any contingency, from tomorrow on as well. Therefore, since it is impossible to split the surplus from tomorrow onward in any other proportion, the static surplus today has to be split in that proportion as well. Since this reasoning holds for all dates and states, the proposition follows.

Free entry and exit condition. We are now ready to formulate the equilibrium free entry and exit condition governing the measures of searching distributors in each country $h$. This condition requires that the expected profit from entry covers the up-front search cost given by $\chi v\left(s^{t}\right)$,

$$
\pi\left(s^{t}\right) J_{d}\left(p_{d}\left(s^{t}\right) ; s^{t}\right)+\left(1-\pi\left(s^{t}\right)\right) J_{f}\left(p_{d}\left(s^{t}\right) ; s^{t}\right) \leq \chi v_{i}\left(s^{t}\right)
$$

with equality whenever $h>0$.

The left-hand side of the above equation is the expected surplus for the retailer from matching with a producer from the domestic or the foreign country, respectively, and the right-hand side is the search cost incurred to identify such opportunity. 


\section{E. Feasibility and Market Clearing}

Equilibrium must fulfil several market clearing conditions and feasibility constraints.

The aggregate resource constraint is given by

$$
d\left(s^{t}\right)+d^{*}\left(s^{t}\right)+\sum_{i=d, f} a_{i}\left(s^{t}\right)+h\left(s^{t}\right) \chi=z\left(s^{t}\right) F\left(k\left(s^{t-1}\right), l\left(s^{t}\right)\right), \text { all } s^{t} .
$$

It says that the total production in the domestic country $z F(k, l)$ must be equal to the amount of goods sold in the domestic market $d\left(s^{t}\right)$, exported to the foreign country $d^{*}\left(s^{t}\right)$, used in marketing by domestic and foreign producers, and finally, in the distribution of goods at home $h\left(s^{t}\right) \chi($ search cost).

Representativeness assumption imposed on equilibrium allocation implies that the average marketing capital is determined by the choices of the representative producer:

$$
\begin{aligned}
& m_{f}\left(s^{t}\right)=\bar{m}_{f}\left(s^{t}\right), \\
& m_{d}\left(s^{t}\right)=\bar{m}_{d}\left(s^{t}\right), \text { all } s^{t},
\end{aligned}
$$

Finally, the contact probability $\pi\left(s^{t}\right)$ is consistent with the average relative marketing capital accumulated by the producers of each type

$$
\pi\left(s^{t}\right)=\frac{\bar{m}_{d}\left(s^{t}\right)}{\bar{m}_{d}\left(s^{t}\right)+\bar{m}_{f}\left(s^{t}\right)}, \text { all } s^{t},
$$

and the world asset market clears

$$
b\left(s^{t}\right)+x\left(s^{t}\right) b^{*}\left(s^{t}\right)=0, \text { all } s^{t} .
$$


The formal definition of equilibrium is standard and therefore omitted.

\section{Parameterization}

In this section, we describe how we choose functional forms and parameter values. The two key parameters in our model are the elasticity of substitution $\gamma$ and the marketing friction parameter $\phi$. We first describe the data targets we use for these two parameters and then proceed with the description of the remaining targets and parameters.

\section{A. The Elasticity of Substitution $\gamma$ and the Marketing Friction $\phi$}

To choose these two parameters, we use the fact that our model has different predictions for the long-run and the short-run response of imports to the relative price fluctuations. Evidence of a similar discrepancy has been documented for the data and in the literature is termed the elasticity puzzle ${ }^{26}$ Below we show how we use long-run and short-run measurements to set calibration targets for these two key parameters.

Long-run measurement In our model, when the adjustments of quantities are extended in time, it can be shown that the response of the import ratio $\frac{f}{d}$ to the relative price of the domestic good $d$ to the foreign good $f$ is equal to the elasticity $\gamma$. That is, just as in the frictionless Armington model, we have

$$
\Delta \log \frac{f}{d} \approx-\gamma \Delta T
$$

\footnotetext{
${ }^{26}$ See, for example, Ruhl (2008) for a detailed discussion of this puzzle and an overview of the literature.
} 
where $\Delta T$ denotes the underlying change in the tariff rate measured in percentage points. ${ }^{27}$

Intuitively, the formula says that in the long-run the market expansion friction is slack, and thus the response of trade to tariff change depends solely on the intrinsic elasticity of substitution between the domestic and the foreign goods. In terms of the estimates of the intrinsic elasticity of substitution in the data, the estimates in the literature range from 6 to about 16 . Here we adopt a middle-of-the-pack number of 7.9, reported by Head \& Ries $(2001)$

Short-run measurement Over the business cycle, however, the long-run adjustment of trade flows in response to prices described above is dampened in our model. This is because in the short-run the market expansion friction limits the instantaneous response of quantities to price fluctuations. Since a similar discrepancy has been identified in the data and our model can replicate it, we use it to quantitatively discipline the value of the market expansion friction parameter $\phi$.

To compute this, we use our own measurement of the short-run elasticity estimated from the aggregate time series. Specifically, we compute the business cycle volatility of the ratio of imports to domestic absorption of domestic good $\left(\approx \frac{f}{d}\right.$ in the model) relative to the volatility of the ratio of the underlying price deflators $\left(\approx \frac{p_{d}}{p_{f}}\right.$ in the model). We label the ratio of these volatilities the volatility ratid and compute it for a cross-section of 16 major

\footnotetext{
${ }^{27} \mathrm{We}$ derive this equation in the technical appendix available online at http://www.ssc.wisc.edu/ldrozd/my_files/Appendix1.pdf.

${ }^{28}$ Other long-run oriented studies give similar estimates. See, for example, Hummels (2001), Clausing (2001), or Eaton \& Kortum (2002).

${ }^{29}$ To construct the volatility ratio, we use series on constant and current price values of imports and domestic absorption, where domestic absorption of domestic good is defined by the sum of domestic expenditures less imports, $D A=(C+G)+I-I M$. We next identify the corresponding prices of imports and domestic absorption with their corresponding price deflators (deflators are defined as the ratio of current to constant price values). Denoting the deflator price of domestic absorption of d-good by $P_{D A}$ and the deflator price
} 
OECD countries.

This methodology of measuring short-run elasticity is motivated by the fact that in a large class of models, the demand for domestic and foreign good is modeled by a CES aggregator (9). In such case, it is straightforward to show that the import ratio is tied to the relative price of domestic and imported goods by

$$
\log \frac{f_{t}}{d_{t}}=\gamma \log \frac{p_{d, t}}{p_{f, t}}+\log \frac{\omega_{t}}{1-\omega_{t}} .
$$

(Note that we are allowing for the $\omega$ to be potentially time-varying here.) Under normal conditions (i.e., when the supply curve is an upward-sloping function of the price and the supply shocks are uncorrelated with the $\omega_{t}$-demand shocks), we should expect the correlation between $\log \frac{\omega_{t}}{1-\omega_{t}}$ and $\log \frac{p_{d, t}}{p_{f, t}}$ to be positive. But then, the volatility ratio defined by

$$
V R \equiv \sigma\left(\log \frac{f_{t}}{d_{t}}\right) / \sigma\left(\log \frac{p_{d, t}}{p_{f, t}}\right)
$$

places an upper bound on the value of the intrinsic price elasticity of trade flows $\gamma$, as implied by the following evaluation of $(39)$ :

$$
\gamma=\sigma\left(\log \frac{f_{t}}{d_{t}}\right) / \sigma\left(\log \frac{p_{d, t}}{p_{f, t}}+\frac{1}{\gamma} \log \frac{\omega_{t}}{1-\omega_{t}}\right) \leq \sigma\left(\log \frac{f_{t}}{d_{t}}\right) / \sigma\left(\log \frac{p_{d, t}}{p_{f, t}}\right)=V R .
$$

In particular, in the Armington model with $\omega$ assumed constant, the volatility ratio is exactly

of imports by $P_{I M}$, the volatility ratio is then defined as $\sigma\left(\frac{I M}{D A}\right) / \sigma\left(\frac{P_{D A}}{P_{I M}}\right)$, where $\sigma$ refers to the standard deviation of the logged and H-P-filtered quarterly time series. Note that our volatility ratio places an upper bound on the regression coefficient between the two variables underlying its construction. The regression coefficient, typically used in short-run studies, is the volatility ratio rescaled by the correlation coefficient $\left(\operatorname{reg}(x, y)=\frac{\sigma_{y}}{\sigma_{x}} \rho_{x, y}, \rho_{x, y} \in[-1,1]\right)$. 
equal to the elasticity of substitution $\gamma$. It will later become clear that for our purposes the upper bound estimate is sufficient. (The main results of the paper are only reinforced when lower values of the VR ratio are targeted in calibration.)

The computed values of the volatility ratio, shown in Table 3 , confirm the low values of the short-run price elasticity of trade flows typically found in the literature ${ }^{30}$ At business cycle frequencies, the median value of the volatility ratio is as low as 0.7 for both $\mathrm{H}-\mathrm{P}$ filtered and linearly detrended data. In the model, we use this value as a target for the market expansion parameter $\phi$. However, because the parameter $\phi$ is not the only parameter that affects the value of the volatility ratio in the theoretical economy, the parameter $\phi$ is determined jointly with other parameters of the model, which we describe below.

\section{B. Choice of Parameter Values and Functional Forms}

Here, we describe in detail how we choose the functional forms and benchmark parameter values. We report our choices in Table 4 .

We assume a constant relative risk aversion (CRRA) utility function,

$$
u(c, l)=\frac{\left(c^{\eta}(1-l)^{1-\eta}\right)^{1-\sigma}}{1-\sigma}, \sigma>0,0 \leq \eta \leq 1
$$

and a Cobb-Douglas production function,

$$
F(k, l)=k^{\alpha} l^{1-\alpha}
$$

\footnotetext{
${ }^{30}$ E.g., Blonigen \& Wilson (1999) or Reinert \& Roland-Holst (1992). In contrast to our approach, this literature uses disaggregated data and regression analysis.
} 
The functional form for the Armington aggregator $G$ and marketing technology have already been incorporated into the setup of the model.

Consider first the parameters that can be selected independently from all other parameters by targeting a single moment from the data. This group includes: (i) the discount factor $\beta$, (ii) capital share parameter $\alpha$, (iii) depreciation rate of physical capital $\delta$, and (iv) Armington elasticity $\gamma$. We choose $\beta$ to reproduce the average annual risk-free real interest rate of $4.1 \%, \alpha$ to reproduce the constant share of labor income in GDP of $64 \%, \delta$ to target the investment to GDP ratio of $25 \%{ }^{31}$ and finally, choose the value of $\gamma$ equal to 7.9 (as explained in the previous section). Following the business cycle literature, we choose the value of $\sigma$ equal to 2 . The parameter $\delta_{H}$ we arbitrarily choose equal to 0.1 - implying that the matches in the economy last on average 2.5 years (10 quarters). Sensitivity analysis, presented in a later section, shows that this parameter has a negligible effect on the results.

The remaining parameters need to be jointly determined because there is no one-toone mapping between their values and moments in the data. This group includes: (i) the marketing friction parameter $\phi$, (ii) the up-front search cost $\chi$, (iii) the bargaining power $\theta$, (iv) the home-bias $\omega$, and (v) the consumption share parameter $\eta$. We choose the values of these parameters to target jointly the following moments: (i) median volatility ratio of 0.7 as given in Table 3 (OECD median), (ii) producer markups of $10 \%$ as estimated by Basu \& Fernald (1997), (iii) relative volatility of the real export price $p_{x}$ to the real exchange rate $x$ of $37 \%$ (U.S. data 1980-2004), (iv) standard value for the share of market activities in total

\footnotetext{
${ }^{31}$ We follow here the choice of Backus, Kehoe \& Kydland (1995). This value implies an investment to GDP ratio of about $25 \%$. In the recent data we find, for example, $20 \%$ in the United States, $28 \%$ in Japan, $22 \%$ in Germany, and 21\% in France. The OECD median is close to 20\%. We adopt a bit higher number to make the model comparable to the results documented in the literature.
} 
time endowment of households equal to $30 \%$, (v) imports to GDP ratio of $12 \%$ (U.S. data 1980-2004), and finally, (vi) the share of marketing expenditures to sales on the industry level of $7 \%$ as reported by Lilien \& Little (1976) (also Lilien \& Weinstein (1984)), and (vii) moments of the productivity process as discussed in the next paragraph.

Productivity process We follow a procedure similar to Heathcote \& Perri (2004) to back out the total factor productivity (TFP) residuals $z$ from the data. However, because the model-implied TFP residuals are different from the assumed ones $\sqrt{32}$ we modify the correlation and volatility of the assumed disturbances $\varepsilon, \varepsilon^{*}$, and the $\operatorname{AR}(1)$ persistence parameter so that the model implied residuals match the following targets from the data: (i) volatility of modelgenerated TFP residuals of $0.79 \%$, (ii) the correlation of model-generated TFP residuals of 0.3 , and (iii) autoregressive coefficient of 0.91 . The exact values of these parameters used in the model economies are reported in Table 4.

Finally, we solve the model by taking a second order approximation of the equilibrium conditions as described in Schmitt-Grohe \& Uribe (2004).

\section{Results}

In this section, we confront our model's quantitative predictions with the data ${ }^{33}$ We identify the United States with the domestic country and the aggregate of 18 major OECD countries with the foreign country ${ }^{34}$ Unless otherwise noted, all reported statistics are based on logged and H-P-filtered quarterly time series. The standard model, with which we con-

\footnotetext{
${ }^{32}$ Marketing expenditures are not treated as investment in national accounts, which is reflected in measured TFP. See McGrattan \& Prescott (2005).

${ }^{33}$ In the technical appendix to the paper (available online), we describe how we map actual national accounting procedures onto our model economy.

${ }^{34}$ Detailed list of countries can be found in the Appendix.
} 
trast our results, has been parameterized analogously whenever applicable. Table 4 reports parameter choices in the theoretical economies.

Business cycle implications for international prices Table 5 reports the business cycle statistics on comovement and relative volatility of international relative prices. As we can see from this table, the benchmark model successfully accounts for the aggregate patterns discussed in Section 12. (i) real export and real import prices are positively correlated (and positively correlated with the real exchange rate), (ii) relative volatility of the terms of trade to the real exchange rate is about $26 \%$, matching the value of $27 \%$ for U.S. data after cleaning import price data from the influence of volatile fuel prices ${ }^{35}$ and (iii) producers price-tomarket to which they sell - the relative price $\frac{p_{x}}{p_{d}}$ is no longer constant and comoves positively with the real exchange rate. The same table also reveals that none of these features of the data are reproduced by the standard model - which implies exactly the opposite pattern to the data.

We do not report it in the table, but both the standard model and the benchmark model fail to replicate the volatility of the real exchange rate by an order of magnitude, and both models imply a positive correlation between the real exchange rate and the consumption ratio (the Backus-Smith puzzle). In order to make sure that our results would not go away once the properties of the real exchange rate are accounted for, we follow Heathcote \& Perri

\footnotetext{
${ }^{35}$ To arrive at this estimate, we use the price indices for export and import prices disaggregated to a onedigit SITC level by the BLS. We next remove from the index classification SITC-3 (fuels) from both the export and the import price index. We then measure by how much it reduces the standard deviation of the logged and H-P-filtered overall terms of trade $(1983$ - 2005) constructed from the BLS price indices. The result is that the volatility of terms of trade falls from about $1.94 \%$ with fuels to about $1.32 \%$ without fuels. We next obtain the non-fuel statistics for the United States by multiplying the volatility of the terms of trade measured from the deflator prices of exports and imports (as in Table 2) by the correcting ratio derived from the BLS data: $1.32 / 1.94 \approx 0.68$. A slightly larger estimate of about $35 \%$ would be obtained from the BLS data directly (the BLS estimate refers to a fixed weight index, not a deflator price).
} 
(2002) and simulate our model under financial autarky-described in detail in Section 7. Under this modification, the real exchange rate implied by the model is negatively correlated with the consumption ratio and is about four times more volatile. As we can see from Table 7 , all our results still stand.

Business cycle implications for quantities Table 7 reports the statistics on quantities. The benchmark model implies a bit too low international comovement of investment ${ }^{36}(0.03$ model vs. 0.23 data), but it matches the rest of the statistics well. Note that, unlike the standard model, the benchmark model is additionally consistent with the fact that output is more internationally correlated than consumption (data 0.4 output and 0.25 consumption; model 0.35 output 0.23 consumption), addressing the so-called quantity puzzle. Because most of the quantitative discrepancies can be fixed by incorporating additional features (e.g., convex adjustment cost or home production), we can interpret these results that both models match data on the quantity dimension reasonably well given their simplicity.

An additional prediction of our richer framework pertains to the behavior of marketing expenditures over the business cycle. The evidence on the behavior of marketing expenditures over the business cycle is scant. However, annual aggregate figures for advertising expenditures on the national level are readily available from the Statistical Abstract of the United States published by the U.S. Census Bureau. These figures reveal that advertising expenditures are a highly pro-cyclical series; in particular, the share of advertising expenditures in GDP is highly pro-cyclical. This observation is consistent with the predictions of our model.

\footnotetext{
${ }^{36}$ For the most recent subperiod (1986-2000), Heathcote \& Perri (2004) report an international correlation of investment equal to zero.
} 


\section{Mechanics Behind the Results}

Compared to the standard theory, our model brings the aggregate price statistics closer to the data in the following dimensions: (i) the real export and import prices are both positively correlated with the real exchange rate, (ii) terms of trade is less volatile than the real exchange rate, and (iii) producers price-to-market. The goal of this section is to provide an intuitive understanding of these implications of the model.

We start by analyzing the critical features that give rise to the above patterns. These features are: (i) bargaining and (ii) market expansion friction. We then proceed to analyze the sources of the real exchange rate fluctuations.

For expositional purposes, we study the impulse response functions to a one-time positive productivity shock in the domestic country. The primitive shock, for which the impulse responses are plotted, is illustrated in panels $\mathrm{A}$ and $\mathrm{B}$ of Figure 3. Panels $\mathrm{C}$ and $\mathrm{D}$ of Figures 3 and 4 present the response of prices in the benchmark model and in the standard model, respectively. What these figures show is that in the benchmark model the real exchange rate depreciates following the shock (panel $\mathrm{C}$ ), and the real export price $p_{x}$ goes up. At the same time, the price of the same good sold at home $p_{d}$ actually falls (panel D). In contrast, in the standard model these two prices are always equal by the law of one price, and following the shock, both fall ${ }^{37}$ The described feature of our model, labeled in the literature as pricing-to-market, is the major difference between the two environments. Below, we discuss intuitively the key forces that give rise to pricing-to-market in our model.

\footnotetext{
${ }^{37} \mathrm{An}$ immediate consequence of such behavior of export and import prices is that the terms of trade, which can be expressed as the ratio of export to import prices, is no longer more volatile than the real exchange rate.
} 
Bargaining Bargaining sets the stage for pricing-to-market to occur by explicitly linking export and import prices to the valuation of the good by the local retailers. From bargaining equations,

$$
\begin{aligned}
& p_{x}\left(s^{t}\right)=\theta x\left(s^{t}\right) P_{d}^{*}\left(s^{t}\right)+(1-\theta) v\left(s^{t}\right), \\
& p_{d}\left(s^{t}\right)=\theta P_{d}\left(s^{t}\right)+(1-\theta) v\left(s^{t}\right),
\end{aligned}
$$

observe that the wholesale prices of the domestic good not only depend on the marginal cost, $v$ and $v^{*}$, but also on the valuation of the goods by the retailers, $x P_{d}$ and $P_{d}$. This contrasts with the standard model, in which by the law of one price both prices are tied to domestic marginal cost:

$$
\begin{aligned}
& p_{x}\left(s^{t}\right)=v\left(s^{t}\right), \\
& p_{d}\left(s^{t}\right)=v\left(s^{t}\right) .
\end{aligned}
$$

Market expansion friction Bargaining alone, however, is not enough to generate the observed behavior of prices. Without certain dynamic properties of the valuations of the retailers, export and import would still correlate the wrong way in our model. The reason why they do not is because producers face the market expansion friction.

On the macro level, this friction makes the endogenous list of customers respond sluggishly to shocks. As a result, the relative scarcity of domestic and foreign goods remains relatively stable over the business cycle and is also sluggish. This connection can readily be 
seen from the feasibility condition pertaining to the export market:

$$
\frac{d^{*}}{f^{*}}=\frac{H_{d}^{*}}{H_{f}^{*}}=\frac{\left(1-\delta_{h}\right) H_{d,-1}^{*}+\frac{\bar{m}_{d}^{*}}{\bar{m}_{f}^{*}+\bar{m}_{d}^{*}} h^{*}}{\left(1-\delta_{h}\right) H_{f,-1}^{*}+\frac{\bar{m}_{f}^{*}}{\bar{m}_{f}^{*}+\bar{m}_{d}^{*}} h^{*}}
$$

From this formula, observe that the adjustment of the scarcity ratio $\frac{d^{*}}{f^{*}}$ is hardwired to the adjustment of the relative marketing capital,

$$
\frac{\bar{m}_{f}^{*}}{\bar{m}_{f}^{*}+\bar{m}_{d}^{*}}
$$

which, in turn, is subjected to the market expansion friction by (25).

The implication of the market expansion friction described above matters for pricingto-market because it crucially affects the dynamics of retail prices, and thereby the valuation of the good by local retailers. To understand the connection between the market expansion friction and retail prices, consider the implication of 16 for the price of the domestic good sold in the foreign market:

$$
P_{d}^{*}=\omega\left[\omega+(1-\omega)\left(\frac{d^{*}}{f^{*}}\right)^{\frac{\gamma-1}{\gamma}}\right]^{\frac{1}{\gamma-1}}
$$

The above formula reveals two key features. First, retail prices respond only to the change in the scarcity ratio $d / f$, and second, the higher the elasticity of substitution $\gamma$ between these goods, the less sensitive they are to this ratio. Because the elasticity of substitution is set high in our model, and the scarcity ratio moves sluggishly in response to the shocks, the retail prices measured in local consumption units remain almost constant over the business cycle. 
To document this property of the model, panels E and F of Figure 3 present the impulse response functions of the retail prices in response to a $1 \%$ positive productivity shock hitting the domestic country. Comparing with similar plots for the standard model included in panels $\mathrm{E}$ and $\mathrm{F}$ of Figure 4, we note that the scarcity ratio moves about as much in our model as in the standard model, but at the same time these movements translate to almost negligible movements of the retail prices.

How do these features lead to pricing-to-market? As a consequence of retail price sluggishness in their respective local consumption units, following the shock the foreign retail price of the domestic good expressed in the domestic consumption units $x P_{d}^{*}$ increases almost one-to-one with the real exchange rate $x$. This is illustrated in panel $\mathrm{E}$ of Figure 3 .

Now, because $x P_{d}^{*}$ is the foreign retailer's valuation of the exported good that enters the bargaining problem summarized by (44), such an increase creates an extra surplus from trade within each existing match. If the bargaining power of the producer $1-\theta$ is positive, this extra surplus partially goes to the domestic producer and results in increased markups on the exported goods. This increase in markups leads to an increase in the export price $p_{x}$, despite the fall of the price of the same good sold at home. Panels C and D of Figure 3 illustrate this effect.

Sources of incomplete arbitrage The above analysis leads to the natural question about the source of incomplete arbitrage in our model. Clearly, the price differential between the home and the export market seen in panel D of Figure 3 encourages domestic producers to relocate sales from the less profitable home market to the more profitable export market. 
What precludes them from taking advantage of this price difference?

The key reason is the fact that in this model the producers, in order to sell more in the foreign market, first need to match with buyers there and expand their customer list. This creates a wedge between the shadow cost of finding a marginal customer abroad and the shadow cost of finding a marginal customer at home. This wedge makes pricing-to-market sustainable and allows the export price $p_{x}$ to persistently depart from the home price $p_{d}$. This wedge can be directly identified in the first order conditions to the producer problem, which are given by

$$
p_{x}\left(s^{t}\right)=v\left(s^{t}\right)+\Lambda_{d}^{*}
$$

where $\Lambda_{d}^{*}$ is the shadow cost of matching with an additional customer abroad, given by

$$
\Lambda_{d}^{*}=\lambda_{d}^{*}\left(s^{t}\right)-\left(1-\delta_{h}\right) E\left[Q\left(s^{t+1} \mid s^{t}\right) \lambda_{d}^{*}\left(s^{t+1}\right)\right]
$$

where

$$
\begin{aligned}
\lambda_{d}\left(s^{t}\right)= & \frac{\bar{m}\left(s^{t}\right)}{h\left(s^{t}\right)} \frac{v\left(s^{t}\right)}{1-2 \phi\left(\frac{a_{d}\left(s^{t}\right)}{m_{d}\left(s^{t-1}\right)}-\delta_{m}\right)} \\
& -\frac{\bar{m}\left(s^{t}\right)}{h\left(s^{t}\right)} E\left[Q\left(s^{t+1} \mid s^{t}\right) v\left(s^{t+1}\right) \frac{1-\delta_{m}-\phi\left[\delta_{m}^{2}-\left(\frac{a_{d}\left(s^{t+1}\right)}{m_{d}\left(s^{t}\right)}\right)^{2}\right]}{1-2 \phi\left(\frac{a_{d}\left(s^{t}\right)}{m_{d}\left(s^{t-1}\right)}-\delta_{m}\right)} .\right.
\end{aligned}
$$

Without these additional time-varying shadow costs, markups would not be time-varying and bargaining would not have any bite. It is the combination of the two frictions that makes prices move the right way. 


\section{Real exchange rate fluctuations and deviations from law of one price (LOP) Even}

though the real exchange rate moves in the benchmark model similarly to the standard model, these movements arise from a different source, and unlike in the standard model, can almost entirely be attributed to the deviations from the law of one price. Below, we first explain the forces that drive real exchange rate fluctuation in our model, and then show how real exchange rate fluctuations are intimately related to the deviations from the law of one price.

The benchmark model is calibrated to reproduce the share of imports in GDP of $12 \%$ (as in U.S. data). Thus, in equilibrium both domestic and foreign country consumers predominately consume their home good, and the market shares of the producers are larger in their home country rather than abroad, i.e., $\pi>1-\pi$ and $\pi^{*}>1-\pi^{*}$, respectively. As we explain below, this asymmetry in market shares, when combined with the market expansion friction, is critical to give rise to real exchange rate fluctuations ${ }^{38}$ A similar effect arises also in the standard model, but it is there instead driven by the combination of the home-bias with the low Armington elasticity $\gamma$. In our model, this effect is weak due to the high value of the elasticity parameter $\gamma$, and consequently, most of the real exchange fluctuations come from the new channel of sluggish market shares.

To illustrate the mechanism at work here, consider a positive productivity shock in the domestic country. Such shock makes good $d$ more abundant, and there are two channels through which the additional supply of good $d$ can be shipped to the households in each country. The retailers can search more intensively ( $h$ and $h^{*}$ go up), or alternatively, the market shares at home and abroad can adjust towards the more abundant domestic good $(\pi$

\footnotetext{
${ }^{38}$ Without the home-bias, i.e., when $\omega=\frac{1}{2}$, the real exchange rate does not move over the business cycle either in our model or in the standard model.
} 
and $1-\pi^{*}$ go up). This link can be established from the following feasibility condition,

$$
h \pi+h^{*}\left(1-\pi^{*}\right)-\delta\left(H_{d}+H_{d}^{*}\right)=\Delta(z F(k, l)),
$$

where $\Delta(z F(k, l))$ denotes the extra supply of $d$ goods with respect to the previous period.

In the benchmark model, the market expansion friction impairs the adjustment through $\pi$ and $\pi^{*}$, and the asymmetry implied by home-bias $\left(\pi>1-\pi^{*}\right)$ makes search relatively more efficient in the domestic country than the foreign country. As a result, following the shock, the overall cost of supplying the domestic consumption basket $c$ falls relative to the cost of supplying the foreign consumption basket $c^{*}, c$ increases more than $c^{*}$, and in consistency with 20, the real exchange rate depreciates.

Finally, we proceed to show that the real exchange rate fluctuations in the benchmark model can be linked to the the law of one price on the commodity level. Using the equations for the shadow prices and the bargaining equations together with (14), (32), and (48), by definition of the the real exchange rate as the ratio of the price of foreign consumption basket to the price of domestic consumption basket measured in common unit, we have

$$
x \equiv \frac{C P I^{*}}{C P I}=\frac{\left(\left(P_{f}+\frac{1}{\theta}\left(x \Lambda_{f}^{*}-x \Lambda_{f}\right)\right)^{1-\gamma} \omega^{\gamma}+\left(P_{d}+\frac{1}{\theta}\left(\Lambda_{d}^{*}-\Lambda_{d}\right)\right)^{1-\gamma}(1-\omega)^{\gamma}\right)^{\frac{1}{1-\gamma}}}{\left(P_{d}^{1-\gamma} \omega^{\gamma}+P_{f}^{1-\gamma}(1-\omega)^{\gamma}\right)^{\frac{1}{1-\gamma}}} .
$$

By the above formula, note that the movements of the real exchange rate can be attributed here to two sources. First, they can be driven by the relative price movements of the price of the domestic good relative to the foreign good $\frac{P_{f}}{P_{d}}$ - just like in the standard model. Second, they may additionally come from the shadow cost differences between the 
domestic and the foreign market (deviations from LOP), $x \Lambda_{f}^{*}-x \Lambda_{f}$ and $\Lambda_{d}^{*}-\Lambda_{d}$, respectively. Figure 5 decomposes the movements of the real exchange rate into these two forces to examine their relative contribution. The first series included shows the behavior of a hypothetical real exchange rate without the shadow price terms,

$$
\hat{x} \equiv \frac{\left(P_{f}^{1-\gamma} \omega^{\gamma}+P_{d}^{1-\gamma}(1-\omega)^{\gamma}\right)^{\frac{1}{1-\gamma}}}{\left(P_{d}^{1-\gamma} \omega \gamma+P_{f}^{1-\gamma}(1-\omega)^{\gamma}\right)^{\frac{1}{1-\gamma}}}
$$

and the second series shows the actual real exchange given by (53) above. From this decomposition, observe that the shadow terms and thus the deviations from the law of one price are the dominant force. (This prediction is broadly consistent with the evidence from Goldberg \& Campa (2008) showing that the retail prices of imported goods carry much less volatility than the real exchange rates.)

\section{Robustness and Sensitivity}

In this section, we examine the robustness of our results to changes in parameter values, and calibration targets used to parameterize the model.

In the first exercise, we show that the sources of dynamics of the real exchange rate do not affect the pricing-to-market predictions of our model, and thus neither the volatility puzzle nor the Backus-Smith puzzle affect the key mechanism of our model. To boost the volatility of the real exchange rate, we consider a variant of our economy in which we assume financial autarky. In the next two exercises, we are interested in the impact of the assumed value of match destruction rate $\delta_{h}$, which we set arbitrarily equal to $\delta_{h}=0.1$ in the benchmark parameterization, and the share of marketing expenditures in GDP, for which we lack 
good data. We show that possible disturbance to the value of $\delta_{h}$ or the share of marketing expenditures to GDP has little impact on the overall results. The last exercise answers the question of whether a simple adjustment cost as explicitly suggested by Krugman (1986) can generate the same behavior of prices as our marketing friction. We find that it can account for some observations, but fails to account for the excess volatility of the real exchange rate relative to the terms of trade.

We report the results of four alternative parameterizations corresponding to the above cases: (i) financial autarky (ii) one-period matches, (iii) low marketing, and (iv) adjustment cost in BKK. The results of these exercises are presented in Table 7 .

Financial autarky This exercise demonstrates that the price dynamics generated by our model relative to the real exchange rate do not depend on the driving forces behind exchange rate movements. In particular, in this exercise we assume that countries are in financial autarky, which increases the volatility of the real exchange rate to the levels observed in the data. In particular, we impose the condition that the current account be zero at each date and state

$$
x\left(s^{t}\right) p_{d}^{*}\left(s^{t}\right) d^{*}\left(s^{t}\right)+v_{d}\left(s^{t}\right) a_{f}\left(s^{t}\right)=p_{f}\left(s^{t}\right) f\left(s^{t}\right)+x\left(s^{t}\right) v_{f}\left(s^{t}\right) a_{d}^{*}\left(s^{t}\right)
$$

The rest of the parameters are chosen to match the same targets as in the benchmark case. Results of this exercise are reported in Table 7. We can see that for the price statistics, changing the real exchange rate dynamics does not affect the relative price dynamics in our model. In particular, the model still matches the import and export price comovement, as 
well as the volatilities of these prices and the terms of trade relative to the real exchange rate.

One-period matches In this quantitative exercise, we show that the long-lasting nature of matches in the benchmark model does not play a crucial role in generating our results. The only critical elements are bargaining and market expansion friction. To establish this result, we set the destruction rate of matches to one, $\delta_{h}=1$, and recalibrate the remaining parameters to hit the same targets as in the benchmark model. The resulting parameterization is reported in Table 4 , and quantitative results are reported in Table $7^{39}$

From Table 7, we see that the implied statistics of the recalibrated model are very close to the benchmark model. The only notable difference is a negative international correlation of investment, which is counterfactual. We conclude that the long-lasting nature of relationships doesn't play a critical role in the model, but somewhat enhances the results. The intuition is straightforward. Because of continual renegotiation of prices, there are no reputational effects of long-lasting nature of relationships in the model, and all sluggishness can be captured in meeting probabilities $\left(\pi, \pi^{*}\right)$ instead of customer lists $(H)$. This is reflected in the parameter choices of Table 4 - shutting down long-lasting matches requires doubling the adjustment cost parameter $\phi$.

Low marketing In this exercise, we check the robustness of our results against the target for marketing to GDP ratio. Data on marketing are scant, and the estimates we use in the benchmark calibration is the median marketing to sales ratio for the United States of $7 \%$ reported by Lilien \& Little (1976) (and also Lilien \& Weinstein (1984)). We treat this value

\footnotetext{
${ }^{39}$ Shutting down long-lasting matches precludes us from matching the autocorrelation of the TFP residuals in the model. Even if we assume that the exogenous process has a correlation of almost one, the model implied autocorrelation is going to be lower than our target of 0.91 .
} 
as the upper bound of this target, and as a robustness check consider an economy with a lower target than the benchmark value. We choose $2.5 \%$ of marketing to GDP, which is the value of advertising/GDP taken from Coen (2007) - arguably a lower bound for marketing expenditures. We recalibrate all parameters to hit the same targets as in the benchmark economy, and report the results in Table 7. As we can see, the predictions of the model do not change much. We conclude that within the crude range suggested by the evidence, the particular value of marketing/GDP targeted in calibration does not affect the results.

Adjustment cost in BKK This last exercise answers the question of whether a simple adjustment cost suggested by Krugman (1986) could generate quantitatively similar behavior of prices as our micro-founded frictions. Krugman argued that a convex tariff would induce producers to price-to-market and potentially account for the observed behavior of prices. In the spirit of Krugman (1986), we introduce a crude quadratic adjustment cost directly on the quantity exported for producers in the standard BKK model. In particular, the domestic producers solve the following problem:

$$
\max \sum \int_{s^{t}} Q\left(s^{t}\right)\left[P_{d}\left(s^{t}\right) d\left(s^{t}\right)+x\left(s^{t}\right) P_{d}^{*}\left(s^{t}\right) d^{*}\left(s^{t}\right)-w\left(s^{t}\right) l\left(s^{t}\right)-r\left(s^{t}\right) k\left(s^{t}\right)\right]
$$

subject to

$$
d\left(s^{t}\right)+d^{*}\left(s^{t}\right)=f\left(s^{t}\right)\left(k\left(s^{t}\right), l\left(s^{t}\right)\right)-\psi_{1}\left(\frac{d\left(s^{t}\right)}{d\left(s^{t-1}\right)}-1\right)^{2}-\psi_{2}\left(\frac{d^{*}\left(s^{t}\right)}{d^{*}\left(s^{t-1}\right)}-1\right)^{2},
$$

where $\psi_{1}$ and $\psi_{2}$ are the adjustment costs for changing the sales in the domestic and foreign market, respectively. 
In the first exercise, we follow Krugman literally and set the adjustment cost only on exports (and imports), i.e., $\psi_{1}=0, \psi_{2}>0$. In this case, we find that for very high values of the adjustment cost, the import and export prices do become positively correlated, but the export price is still negatively correlated with the real exchange rate. Because they also become increasingly volatile, the terms of trade is more volatile than the real exchange rate, and the volatility of the export price is more than 2.5 times that of the real exchange rate 40

We next try a more parsimonious way of introducing this cost by imposing a symmetry between the home market and the export market. In our second experiment, reported in Table 7. we set $\psi_{1}=\psi_{2}=\psi>0$ and increase this cost until we obtain a positive correlation between export price and the real exchange rate. In this case, we find that the correlation between the real exchange rate and the export price does become positive, but the model comes nowhere near replicating the volatilities of the export and import prices relative to the real exchange rate. It also fails to replicate the volatility of GDP and matches quantity statistics very poorly. In addition, unlike the benchmark model, the standard model with a crude convex adjustment cost on quantities no longer accounts for the elasticity puzzle, as it is able to match only one of the price elasticities of trade flows. This is true despite the fact that trade flows are dampened and sluggish due to the adjustment cost. The problem is that unlike in the benchmark model, here producer prices are equal to retail prices, and thereby intimately linked to the product mix ratio $\frac{f}{d}$ and $\frac{f^{*}}{d^{*}}$ through the consumer first order conditions 16 . These conditions fix the volatility of the price ratio $\frac{p_{d}}{p_{f}}$ relative to the quantity ratio $\frac{d}{f}$, and consequently both short-run and long-run price elasticity of trade flows are roughly equal to $\gamma$. In the benchmark model, by bargaining (44), this tight link is severed, and producer prices

\footnotetext{
${ }^{40}$ Results not reported. Available on request from the authors.
} 
move differently than the retail prices. Concluding, even though the model with convex cost can imply pricing-to-market, it falls short in important dimensions.

\section{Conclusions}

In this paper, we have demonstrated that dynamic frictions of building market shares have the potential to account for pricing-to-market, and the discrepancy between the shortrun and the long-run price elasticity of trade flows. Given the anecdotal evidence about the importance of switching costs and the long-lasting nature of producer-supplier relations in international trade, we believe that the mechanism proposed by us is an important step toward a better understanding of the fundamental reasons behind the deviations from the law of one price. 


\section{Appendix}

A more detailed technical appendix is available online at

http://www.ssc.wisc.edu/ldrozd/my_files/Appendix1.pdf. Here we list our data sources and define formally the aggregate prices of interest.

\section{A1. Definition of Aggregate Price Indices}

The real export (import) price has been constructed by dividing the nominal deflator price of export:41 (imports) by the all-items CPI,

$$
p_{x}=\frac{E P I}{C P I}\left(p_{m}=\frac{I P I}{C P I}\right),
$$

where EPI $(I P I)$ is the nominal deflator prices of exports (imports) constructed by dividing the value of exports in current prices by the value of export in constant prices. $p_{x}^{T}\left(p_{m}^{T}\right)$ has been constructed from the formula in the paper additionally using the CPI for housing and services to measure the prices of non-tradables $P^{N}$ (see description of the data below). In Table 2 the real exchange rate has been constructed by us by dividing the trade-weighted foreign price level index by the corresponding domestic price level index, after prior conversion to a common numeraire (using nominal exchange rate),

$$
x_{i} \equiv \Pi_{j=1}^{N}\left(e_{i j} P_{j}\right)^{\omega_{i j}} / P_{i},
$$

where $x_{i}$ is the real exchange rate of country $i, e_{i j}$ denotes the bilateral nominal exchange rate between country $i$ and country $j$ ( $j$ currency units in terms of domestic currency), $\omega_{i j}$ denotes the weight of country $j$ in total trade $\left(\sum_{j}^{N} \omega_{j}=1\right)$ of country $i$, and $P_{i}$ is the price index used to measure the overall price level. In all other cases, we used the trade-weighted time series from the IMF-IFS database. The terms of trade has been constructed as follows:

$$
p=\frac{I P I}{E P I}
$$

\section{A2. Proof of Proposition 1}

We will prove the proposition for a generic match of a domestic retailer with a foreign producer. Other cases follow by analogy. Define the total surplus from a given match by $S=J+W$, and note that (31) implies that at every date and state $s^{t}$

$$
W\left(s^{t}\right)=\theta S\left(s^{t}\right)
$$

where

$$
S\left(s^{t}\right)=\max \left\{\theta\left(P_{f}\left(s^{t}\right)-x\left(s^{t}\right) v^{*}\left(s^{t}\right), 0\right\}+\theta\left(1-\delta_{H}\right) E_{t}\left\{Q\left(s_{t+1} \mid s^{t}\right) S\left(s^{t+1}\right)\right\} .\right.
$$

Thus, we have by definition of $W$

$$
\left.W\left(s^{t}\right)=\max \left\{p_{f}\left(s^{t}\right)-x\left(s^{t}\right) v^{*}\left(s^{t}\right)\right), 0\right\}+\left(1-\delta_{H}\right) E_{t}\left\{Q\left(s_{t+1} \mid s^{t}\right) W\left(s^{t+1}\right)\right\},
$$

and by $\mathrm{A} 4$ and $\mathrm{A} 5$ also

$$
W\left(s^{t}\right)=\theta S\left(s^{t}\right)=\max \left\{\theta\left(P_{f}\left(s^{t}\right)-x\left(s^{t}\right) v^{*}\left(s^{t}\right)\right), 0\right\}+\left(1-\delta_{H}\right) E_{t}\left\{Q\left(s_{t+1} \mid s^{t}\right) W\left(s^{t+1}\right)\right\} .
$$

\footnotetext{
${ }^{41}$ The nominal deflator price of exports (imports) is defined as the ratio of value of exports (imports) in current prices to the value of exports (imports) in constant prices.
} 
Subtracting side-by-side (A6) and (A7), and assuming that trade surplus is positive (i.e., trade takes place), we obtain the fixed-surplus-splitting rule given by

$$
p_{f}\left(s^{t}\right)-x\left(s^{t}\right) v^{*}\left(s^{t}\right)=\theta\left(P_{f}\left(s^{t}\right)-x\left(s^{t}\right) v^{*}\left(s^{t}\right)\right) .
$$

\section{A3. Data Sources}

Table 1, 2: OECD Main Economic Indicators, SourceOECD.org, International Financial Statistics by IMF (2005), OECD Main Indicators Printed Edition and SourceOECD.org (housing-services and all-items CPI series). Table 3 OECD Main Economic Indicators, SourceOECD.org. Countries included as rest-of-the-world are: Austria, Belgium, Denmark, Finland, France, Germany, Greece, Ireland, Italy, Luxembourg, the Netherlands, Portugal, Spain, Sweden and the United Kingdom, Switzerland, Canada, Australia, Japan. Data for the U.S. hours worked come from the Current Population Survey by the Bureau of Labor Statistics, and has been compiled by Prescott, Ueberfeldt \& Cociuba (2008). We thank Simona Cociuba and Ellen McGrattan for this dataset. Price Data for Japan: The dataset has been compiled by Bank of Japan from monthly survey of producer/wholesale prices: Yen-based price indices for exports (f.o.b.) and domestic prices (wholesale or corporate level prices that include only domestically-produced and domestically-used goods). Final series have been seasonally adjusted (using Demetra 2.0, tramo-seats method) and Hodrick-Prescott filtered with a smoothing parameter of 1600 .

\section{References}

Alessandria, G. 2004. "International Deviations from the Law of One Price: The Role of Search Frictions and Market Share." International Economic Review 45(4):1263-1291.

Alessandria, G. 2005. "Consumer Search, Price Dispersion and International Relative Price Volatility." Federal Reserve Bank of Philadelphia Working Paper 05-9.

Armington, P. S. 1969. "A Theory of Demand for Products Distinguished by Place of Production." International Monetary Fund Staff Papers 16(1):159-178.

Atkeson, A. \& A. T. Burstein. forthcoming. "Pricing-to-Market, Trade Costs, and International Relative Prices." American Economic Review .

Backus, D. K., P. J. Kehoe \& F. E. Kydland. 1995. International Business Cycles: Theory and Evidence. In Frontiers of Business Cycle Research, ed. T. Cooley. Chapter 11, pp. 331-356, Princeton, NJ: Princeton University Press.

Basu, S. \& J. G. Fernald. 1997. "Returns to Scale in U.S. Production: Estimates and Implications." Journal of Political Economy 105(2):249-283.

Baxter, M. 1995. "International Trade and Business Cycles." NBER Working Paper 5025, National Bureau of Economic Research.

Blonigen, B. A. \& W. W. Wilson. 1999. "Explaining Armington: What Determines Substitutability Between Home and Foreign Goods?" Canadian Journal of Economics 32(1):122. 
Chari, V. V., P. J. Kehoe \& E. McGrattan. 2002. "Can Sticky Price Models Generate Volatile and Persistent Real Exchange Rates?" Review of Economic Studies 69(3):533-563.

Clausing, K. A. 2001. "Trade Creation and Trade Diversion in the Canada - United States Free Trade Agreement." Canadian Journal of Economics 34(3):677-696.

Coen, Robert. 2007. "Insider's Report: Robert Coen Presentation on Advertising Expenditures." UniversalMcCann (December).

Eaton, J. \& S. Kortum. 2002. "Technology, Geography, and Trade." Econometrica 70(5):1741-1779.

Egan, M. L. \& A. Mody. 1992. "Buyer Seller Links in Export Development." World Development 20(3):321-334.

Froot, K. A. \& P. D. Klemperer. 1989. "Exchange Rate Pass-Through When Market Share Matters." American Economic Review 79(4):637-654.

Ghironi, F. \& M. J. Melitz. 2005. "International Trade and Macroeconomic Dynamics with Heterogeneous Firms." Quarterly Journal of Economics 120(3):865-915.

Goldberg, L. \& J. Campa. 2008. "The Insensitivity of CPI to Exchange Rates: Distribution Margins, Imported Inputs, and Trade Exposure." NBER Working Paper 8934, National Bureau of Economic Research.

Goldberg, P. K. \& M. M. Knetter. 1997. "Goods Prices and Exchange Rates: What Have We Learned?" Journal of Economic Literature 35(3):1243-1272.

H. Hakansson, ed. 1982. International Marketing and Purchasing of Industrial Goods. IMP Project Group. Chichester: Wiley and Sons.

Head, K. \& J. Ries. 2001. "Increasing Returns Versus National Product Differentiation as an Explanation for the Pattern of U.S.-Canada Trade." American Economic Review 91(4):858-876.

Heathcote, J. \& F. Perri. 2002. "Financial Autarky and International Business Cycles." Journal of Monetary Economics 49(3):601-627.

Heathcote, J. \& F. Perri. 2004. "Financial Globalization and Real Regionalization." Journal of Economic Theory 119(1):207-243.

Hummels, D. 2001. "Toward a Geography of Trade Costs." unpublished manuscript, Purdue University.

International Financial Statistics. 2005. International Monetary Fund.

Knetter, M. M. 1993. "International Comparisons of Price-to-Market Behavior." American Economic Review 83(3):473-486. 
Krugman, P. 1986. "Pricing-to-Market When the Exchange Rate Changes." NBER Working Paper 1926, National Bureau of Economic Research.

Kydland, F. E. \& E. C. Prescott. 1982. "Time to Build and Aggregate Fluctuations." Econometrica 50(6):1345-1370.

Lilien, G. L. \& D. Weinstein. 1984. "An International Comparison of the Determinants of Industrial Marketing Expenditures." Journal of Marketing 48(1):46-53.

Lilien, G. L. \& J. D. C. Little. 1976. "The ADVISOR Project: A Study of Industrial Marketing Budgets." Sloan Management Review 17(3):17-31.

Marston, R. C. 1990. "Pricing to Market in Japanese Manufacturing." Journal of International Economics 29(3/4):217-236.

McGrattan, E. \& E. C. Prescott. 2005. "Productivity and the Post-1990 U.S. Economy." Federal Reserve Bank of St. Louis Review 87(4):537-49.

Mendoza, E. G. 1991. "Real Business Cycles in a Small Open Economy." American Economic Review 81(4):797 818.

Mortensen, D. T. 1982. "Property Rights and Efficiency in Mating, Racing, and Related Games." American Economic Review 72(5):968-979.

OECD Main Economic Indicators. 2007. SourceOECD.org.

Pissarides, C. A. 1984. "Efficient Job Rejection." Economic Journal (supplement) 94(376a):97-108.

Prescott, E. C., A. Ueberfeldt \& S. Cociuba. 2008. "U.S. Hours and Productivity Behavior Using CPS Hours Worked Data: 1959-I to 2007-IV." Manuscript, Federal Reserve Bank of Dallas.

Reinert, K. A. \& D. W. Roland-Holst. 1992. "Armington Elasticities for United States Manufacturing Sectors." Journal of Policy Modeling 14(5):631-639.

Rogoff, M. 1996. "The Purchasing Power Parity." Journal of Economic Literature 34(2):647668.

Ruhl, K. J. 2008. "The International Elasticity Puzzle." University of Texas-Austin unpublished manuscript.

Ruhl, K. J. \& J. L. Willis. 2008. "Convexities, Nonconvexities, and Firm Export Behavior." Manuscript, Midwest Macro Conference, Philadelphia.

Schmitt-Grohe, S. \& M. Uribe. 2004. "Solving Dynamic General Equilibrium Models Using a Second-Order Approximation to the Policy Function." Journal of Economic Dynamics and Control 28(4):755-775. 
Stockman, A. C. \& L. Tesar. 1995. "Tastes and Technology in a Two-Country Model of the Business Cycle: Explaining International Comovements." American Economic Review 85(1):169-185.

Turnbull, P. W. \& eds. M. T. Cunningham. 1981. International Marketing and Purchasing. Houndmills, Basingstoke, Hampshire, U.K: Palgrave Macmillan. 
Table 1: Correlation of Real Export and Real Import Prices

\begin{tabular}{lcccccc}
\hline \multirow{2}{*}{ Country } & \multicolumn{6}{l}{ Correlation } \\
\cline { 2 - 7 } & $p_{x}, p_{m}$ & $p_{x}, x$ & $p_{m}, x$ & $p_{x}^{T}, p_{m}^{T}$ & $p_{x}^{T}, x$ & $p_{m}^{T}, x$ \\
\hline Australia & 0.57 & 0.45 & 0.95 & n.a & n.a & n.a \\
Belgium & 0.94 & 0.72 & 0.74 & 0.91 & 0.64 & 0.65 \\
Canada & 0.71 & 0.50 & 0.92 & 0.72 & 0.48 & 0.86 \\
France & 0.90 & 0.61 & 0.66 & 0.89 & 0.60 & 0.62 \\
Germany & 0.62 & 0.50 & 0.85 & 0.47 & 0.28 & 0.84 \\
Italy & 0.88 & 0.68 & 0.72 & 0.84 & 0.65 & 0.67 \\
Japan & 0.85 & 0.92 & 0.85 & 0.84 & 0.90 & 0.85 \\
Netherlands & 0.94 & 0.76 & 0.80 & 0.92 & 0.75 & 0.78 \\
Sweden & 0.89 & 0.60 & 0.74 & n.a & n.a & n.a \\
Switzerland & 0.60 & 0.51 & 0.83 & 0.51 & 0.44 & 0.86 \\
UK & 0.90 & 0.61 & 0.79 & n.a & n.a & n.a \\
US & 0.75 & 0.46 & 0.69 & 0.68 & 0.46 & 0.69 \\
\hline MEDIAN & 0.87 & 0.61 & 0.80 & 0.84 & 0.60 & 0.78 \\
\hline
\end{tabular}

Notes: Prices as defined in the data section. Statistics based on logged \& H-P-filtered quarterly time series. Except for $\mathrm{T}$ series, which ends in year 2000, the series range from 1980:1 to 2004:2. Sources are listed in the Appendix.

Table 2: Volatility of Terms of Trade Relative to Real Exchange Rate

\begin{tabular}{llcc}
\hline & \multicolumn{3}{l}{ Volatility of $p$ relative to $x$ (in $\%)$} \\
\cline { 2 - 4 } Country & \multicolumn{2}{l}{ Price index used to construct ${ }^{a} x$} & \\
\hline Australia & CPI all-items & WPI or PPI & None (nominal) \\
Belgium & 0.51 & 0.54 & 0.60 \\
Canada & 0.57 & 0.70 & 0.47 \\
France & 0.56 & 0.76 & 0.61 \\
Germany & 0.80 & 0.74 & 0.73 \\
Italy & 0.83 & 0.81 & 0.80 \\
Japan & 0.75 & 0.79 & 0.77 \\
Netherlands & 0.52 & 0.54 & 0.55 \\
Sweden & 0.52 & 0.49 & 0.44 \\
Switzerland & 0.21 & 0.21 & 0.37 \\
UK & 0.71 & 0.68 & 0.67 \\
US & 0.30 & 0.32 & 0.37 \\
\hline MEDIAN & 0.31 & 0.33 & 0.28 \\
\hline
\end{tabular}

Notes: We have constructed trade-weighted exchange rates using weights and bilateral exchange rates for the set of 11 fixed trading partners for each country. The trading partners included in the sample are the countries listed in this table. Statistics are computed from logged and H-P-filtered quarterly time-series for the time period 1980:1-2000.01 $(\lambda=1600)$. Data sources are listed at the end of the paper.

${ }^{a}$ Definitions are stated in the Appendix. 
Table 3: Volatility Ratio in a Cross-Section of Countries

\begin{tabular}{lcc}
\hline & \multicolumn{2}{c}{ Detrending method } \\
\cline { 2 - 3 } Country & HP-1600 & Linear $^{a}$ \\
\hline Australia & 0.94 & 0.93 \\
Belgium & 0.57 & 0.50 \\
Canada & 1.27 & 0.64 \\
France & 0.54 & 0.73 \\
Germany & 0.90 & 1.16 \\
Italy & 0.69 & 0.46 \\
Japan & 0.60 & 0.43 \\
Netherlands & 0.44 & 0.72 \\
Switzerland & 0.71 & 1.16 \\
Sweden & 0.95 & 0.95 \\
UK & 0.65 & 0.61 \\
US & 1.23 & 1.02 \\
\hline MEDIAN & 0.71 & 0.73 \\
\hline
\end{tabular}

Notes: Based on quarterly time-series, $1980: 1-2000: 1$. Data sources are listed at the end of the paper. ${ }^{a}$ Linear trend subtracted from logged time series.

${ }^{b}$ For the entire postwar period $(1959: 3-2004: 2)$ this ratio in U.S. is 0.88 . 
Table 4: Parameter Values in the Model Economies

\begin{tabular}{|c|c|}
\hline Model Economy & Parameter Values \\
\hline Benchmark Model & $\begin{array}{l}\text { Preferences and technology: } \beta=0.99, \sigma= \\
2.0, \eta=0.3436, \gamma=7.9, \omega=0.5581, \alpha= \\
0.36, \delta=0.025, \\
\text { Marketing friction: } \theta=0.40, \chi=1.38, \delta_{m}= \\
0.2, \delta_{h}=0.1, \phi=18.4, \\
\text { Productivity process: } \psi=0.735, \quad \operatorname{var}(\epsilon)= \\
0.0000835, \operatorname{corr}\left(\epsilon, \epsilon^{*}\right)=0.2\end{array}$ \\
\hline Standard Model & $\begin{array}{l}\text { Preferences: } \gamma=0.7, \eta=0.3385, \omega=0.945 \text {, } \\
\text { Productivity process: } \psi=0.91, \operatorname{var}(\epsilon)= \\
0.000037, \operatorname{corr}\left(\epsilon, \epsilon^{*}\right)=0.28 \text {; rest as in Bench- } \\
\text { mark. }\end{array}$ \\
\hline Financial Autarky & $\begin{array}{l}\text { Preferences: } \omega=0.5565, \\
\text { Marketing friction: } \theta=0.33, \chi=1.9, \delta_{m}= \\
0.32, \phi=0.17, \\
\text { Productivity process: } \quad \psi=0.84, \operatorname{var}(\epsilon)= \\
0.00008, \operatorname{corr}\left(\epsilon, \epsilon^{*}\right)=0.4\end{array}$ \\
\hline Low Marketing & $\begin{array}{l}\text { Marketing friction: } \delta_{m}=0.0513, \phi=1.94 \\
\text { Productivity process: } \psi=0.8, \operatorname{var}(\epsilon)= \\
0.0001, \operatorname{corr}\left(\epsilon, \epsilon^{*}\right)=0.06 ; \text { rest as in Benchmark. }\end{array}$ \\
\hline One-Period Matches & $\begin{array}{l}\text { Marketing friction: } \delta_{h}=1.0, \delta_{m}=0.0655, \chi= \\
0.15, \phi=50.0, \\
\text { Productivity process: } \quad \psi=0.98, \operatorname{var}(\epsilon)= \\
0.0000335, \operatorname{corr}\left(\epsilon, \epsilon^{*}\right)=0.25 ; \text { rest as in Bench- } \\
\text { mark. }\end{array}$ \\
\hline Adjustment Cost in BKK & $\begin{array}{l}\text { Preferences and technology: } \gamma=0.7, \quad \eta= \\
0.3385, \omega=0.945, v=100.0, \\
\text { Productivity process: } \psi=0.91, \operatorname{var}(\epsilon)= \\
0.000037, \operatorname{corr}\left(\epsilon, \epsilon^{*}\right)=0.28 ; \text { rest as in Bench- } \\
\text { mark. }\end{array}$ \\
\hline
\end{tabular}


Table 5: International Prices: Comparing Theory with Data ${ }^{a}$

\begin{tabular}{|c|c|c|c|}
\hline \multirow[b]{2}{*}{ Statistic } & \multirow[b]{2}{*}{$\operatorname{Data}^{b}$} & \multicolumn{2}{|l|}{ Model Economy } \\
\hline & & $\begin{array}{l}\text { Benchmark } \\
\phi=18.4, \gamma=7.9\end{array}$ & $\begin{array}{l}\text { Standard } \\
\gamma=0.7^{c}\end{array}$ \\
\hline \multicolumn{4}{|l|}{ A. Correlation } \\
\hline$p_{x}, p_{m}$ & 0.75 & 0.98 & -1.00 \\
\hline$p_{x}, x$ & 0.46 & 0.99 & -1.00 \\
\hline$p_{m}, x$ & 0.69 & 1.00 & 1.00 \\
\hline$p, x$ & 0.61 & 0.95 & 1.00 \\
\hline \multicolumn{4}{|c|}{ B. Volatility relative to ${ }^{e} x$} \\
\hline$p_{x}$ & 0.37 & 0.37 & 0.162 \\
\hline$p_{m}$ & 0.61 & 0.62 & 1.16 \\
\hline$p\left(\right.$ no fuels $\left.{ }^{d}\right)$ & 0.27 & 0.26 & 1.32 \\
\hline$p_{x} / p_{d}$ & $\mathrm{n} / \mathrm{a}$ & 0.19 & 0.00 \\
\hline \multicolumn{4}{|c|}{ C. Pass-through coefficient } \\
\hline & 0.68 & 0.62 & 1.16 \\
\hline
\end{tabular}

${ }^{a}$ Statistics based on logged and H-P-filtered time-series with smoothing parameter $\lambda=1600$.

${ }^{b}$ Data column refers to U.S. data for the period $1980: 1-2004: 1$.

${ }^{c}$ This setting of $\gamma$ is consistent with model implied volatility ratio of 0.7 .

${ }^{d}$ Refers to terms of trade series cleaned from the influence of fuels (SITC 3); relative volatility of the overall terms of trade is about 0.41 for U.S.

${ }^{e}$ Ratio of corresponding standard deviation to the standard deviation of the real exchange rate $x$. 
Table 6: Quantities: Comparing Theory with Data ${ }^{a}$

\begin{tabular}{|c|c|c|c|}
\hline \multirow[b]{2}{*}{ Statistic } & \multirow[b]{2}{*}{$\operatorname{Data}^{b}$} & \multicolumn{2}{|l|}{ Model Economy } \\
\hline & & $\begin{array}{l}\text { Benchmark } \\
\phi=18.4, \gamma=7.9\end{array}$ & $\begin{array}{l}\text { Standard } \\
\gamma=0.7^{c}\end{array}$ \\
\hline \multicolumn{4}{|l|}{ A. Correlations } \\
\hline \multicolumn{4}{|c|}{ domestic with foreign } \\
\hline TFP $\left(\right.$ actual $\left.^{e}\right)$ & 0.30 & 0.30 & 0.30 \\
\hline GDP & 0.40 & 0.35 & 0.36 \\
\hline Consumption & 0.25 & 0.23 & 0.32 \\
\hline Employment & 0.21 & 0.32 & 0.48 \\
\hline Investment & 0.23 & 0.03 & 0.16 \\
\hline \multicolumn{4}{|l|}{ GDP with } \\
\hline Consumption & 0.83 & 0.93 & 0.94 \\
\hline Employment & 0.85 & 0.80 & 0.98 \\
\hline Investment & 0.93 & 0.83 & 0.66 \\
\hline Net exports & -0.49 & -0.56 & -0.77 \\
\hline \multicolumn{4}{|c|}{ Terms of trade with } \\
\hline Net exports & -0.17 & -0.89 & -0.81 \\
\hline \multicolumn{4}{|l|}{$\begin{array}{l}\text { B. Volatility } \\
\text { relative to GDP }\end{array}$} \\
\hline Consumption & 0.74 & 0.32 & 0.31 \\
\hline Investment & 2.79 & 3.67 & 3.36 \\
\hline Employment & 0.81 & 0.69 & 0.48 \\
\hline Net exports & 0.29 & 0.21 & 0.13 \\
\hline
\end{tabular}

${ }^{a}$ Statistics based on logged and H-P-filtered time-series with smoothing parameter $\lambda=1600$.

${ }^{b}$ Data column refers to U.S. data for the time period 1980:1-2004:1.

${ }^{c}$ This setting of $\gamma$ is consistent with model implied volatility ratio of 0.7 .

${ }^{d}$ Ratio of corresponding standard deviation to the standard deviation of GDP.

${ }^{e}$ Calculated using actual national accounting procedures; see technical appendix to the paper at http://www.ssc.wisc.edu/ ldrozd/my_files/Appendix1.pdf. 
Table 7: Sensitivity and Robustness ${ }^{a}$

\begin{tabular}{|c|c|c|c|c|c|}
\hline \multirow[b]{2}{*}{ Statistic } & \multirow[b]{2}{*}{ Benchmark } & \multicolumn{4}{|c|}{ Variations on the Theory } \\
\hline & & $\begin{array}{l}\text { Financial } \\
\text { Autarky }\end{array}$ & $\begin{array}{l}\text { Low } \\
\text { Marketing }\end{array}$ & $\begin{array}{l}\text { One-period } \\
\text { Matches }\end{array}$ & $\begin{array}{l}\text { Adjustment Cost } \\
\text { in BKK }\end{array}$ \\
\hline \multicolumn{6}{|c|}{ International Prices } \\
\hline \multicolumn{6}{|c|}{ A. Correlations } \\
\hline$p_{x}, p_{m}$ & 0.98 & 1.00 & 0.97 & 1.00 & 0.28 \\
\hline$p_{x}, x$ & 0.99 & 1.00 & 0.98 & 1.00 & 0.12 \\
\hline$p_{m}, x$ & 1.00 & 1.00 & 0.99 & 1.00 & 0.56 \\
\hline$p, x$ & 0.95 & 0.99 & 0.93 & 0.99 & 0.41 \\
\hline \multicolumn{6}{|c|}{ B. Standard deviation } \\
\hline$x$ & 0.43 & 1.65 & 0.45 & 0.66 & 0.35 \\
\hline \multicolumn{6}{|l|}{ - Relative to $x$} \\
\hline$p_{x}$ & 0.37 & 0.37 & 0.37 & 0.37 & 1.33 \\
\hline$p_{m}$ & 0.62 & 0.63 & 0.64 & 0.63 & 1.6 \\
\hline$p$ & 0.26 & 0.26 & 0.29 & 0.26 & 1.75 \\
\hline$x p_{d}^{*} / p_{d}$ & 0.19 & 0.65 & 0.20 & 0.29 & 0.49 \\
\hline C. P-T coefficient & 0.62 & 0.63 & 0.63 & 0.63 & 0.88 \\
\hline \multicolumn{6}{|l|}{ Quantities } \\
\hline \multicolumn{6}{|l|}{ A. Correlations } \\
\hline \multicolumn{6}{|c|}{ - Domestic with foreign } \\
\hline TFP (actual) & 0.30 & 0.30 & 0.30 & 0.30 & 0.30 \\
\hline GDP & 0.35 & 0.37 & 0.32 & 0.34 & 0.34 \\
\hline Consumption & 0.23 & 0.34 & 0.12 & 0.39 & 0.40 \\
\hline Employment & 0.32 & 0.27 & 0.17 & 0.56 & 0.30 \\
\hline Investment & 0.03 & 0.35 & -0.05 & -0.08 & 0.36 \\
\hline \multicolumn{6}{|l|}{ - GDP with } \\
\hline Consumption & 0.93 & 0.90 & 0.92 & 0.99 & 0.90 \\
\hline Employment & 0.80 & 0.68 & 0.81 & 0.97 & -0.01 \\
\hline Investment & 0.83 & 0.94 & 0.86 & 0.66 & 0.89 \\
\hline Net exports & -0.56 & $\mathrm{n} / \mathrm{a}$ & -0.56 & -0.53 & -0.51 \\
\hline \multicolumn{6}{|c|}{ - Terms of trade with } \\
\hline Net exports & -0.89 & $\mathrm{n} / \mathrm{a}$ & -0.89 & -0.81 & -0.99 \\
\hline \multicolumn{6}{|c|}{ B. Standard deviations } \\
\hline GDP & 1.16 & 1.06 & 1.21 & 0.95 & 0.46 \\
\hline \multicolumn{6}{|c|}{ - Relative to GDP } \\
\hline Consumption & 0.32 & 0.38 & 0.32 & 0.51 & 0.33 \\
\hline Investment & 3.67 & 3.07 & 3.94 & 2.98 & 3.00 \\
\hline Employment & 0.69 & 0.80 & 0.78 & 0.28 & 1.89 \\
\hline Net exports & 0.21 & 0.00 & 0.23 & 0.20 & 0.14 \\
\hline
\end{tabular}

Notes: Same footnotes apply. See tables with results. 

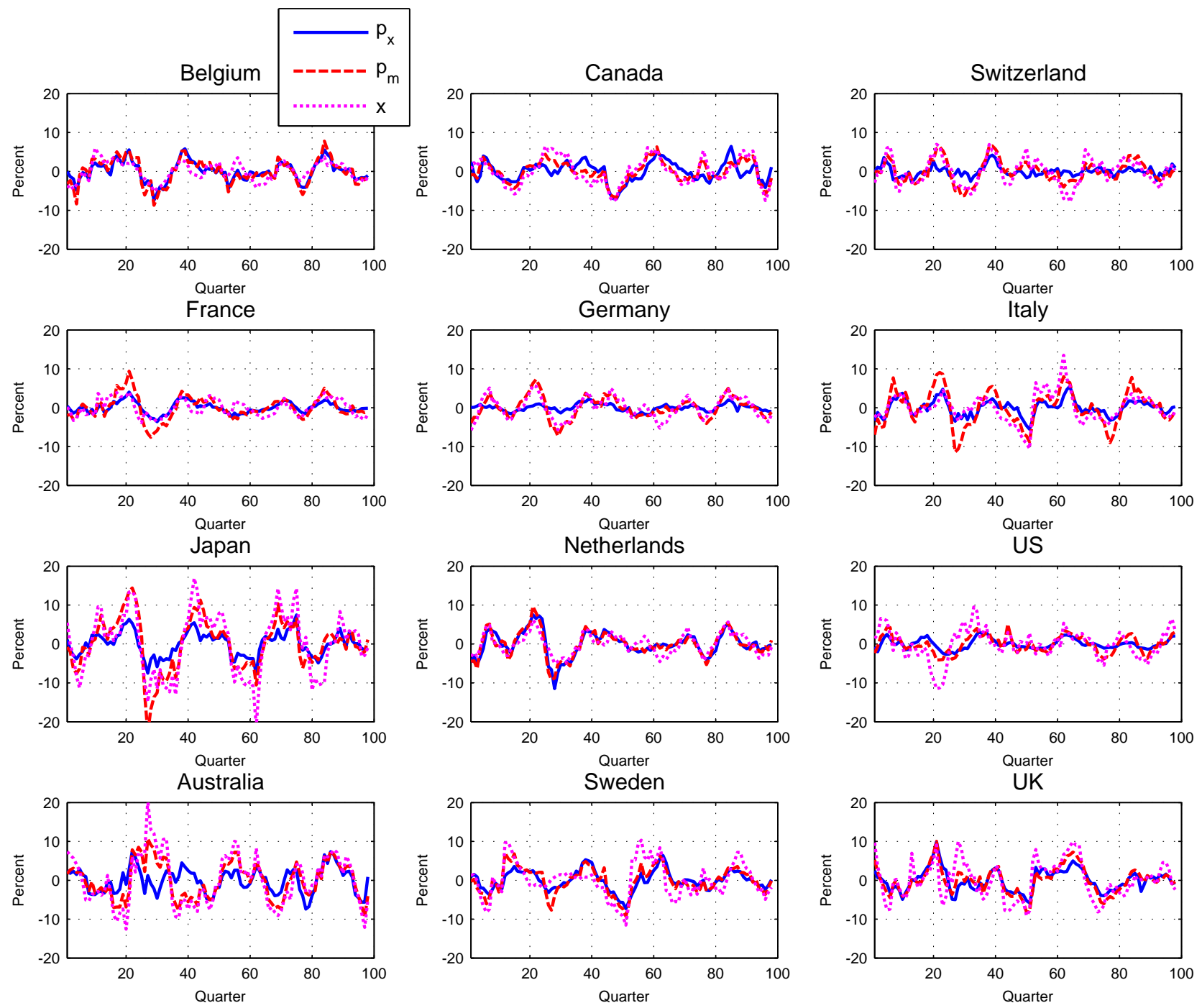

Figure 1: Comovement of real export and import prices in the data. The included series illustrate quarterly H-P-filtered percentage deviations from the trend. 


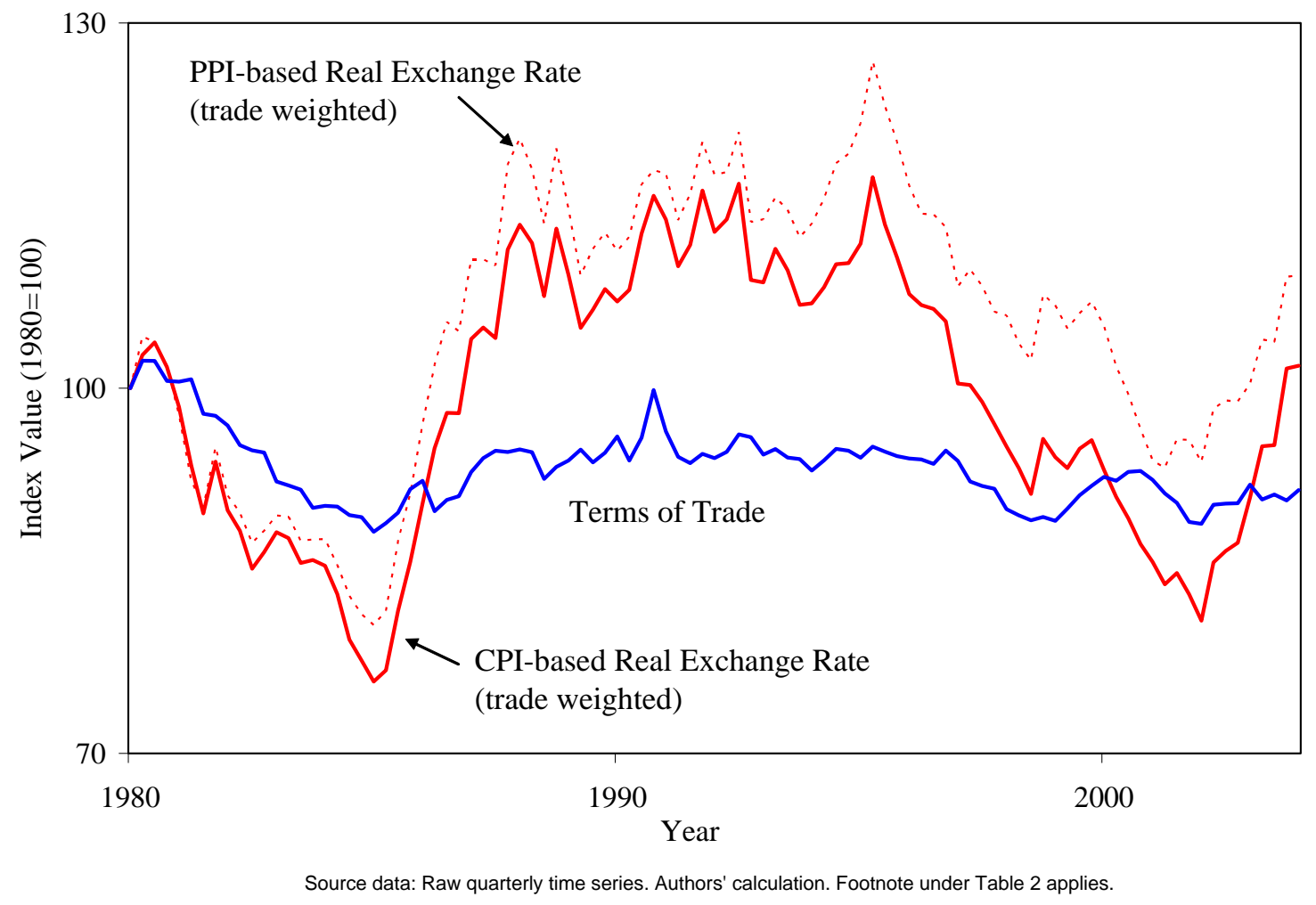

Figure 2: Real exchange rate and terms of trade fluctuations in the U.S. data, $1980-2005$. 

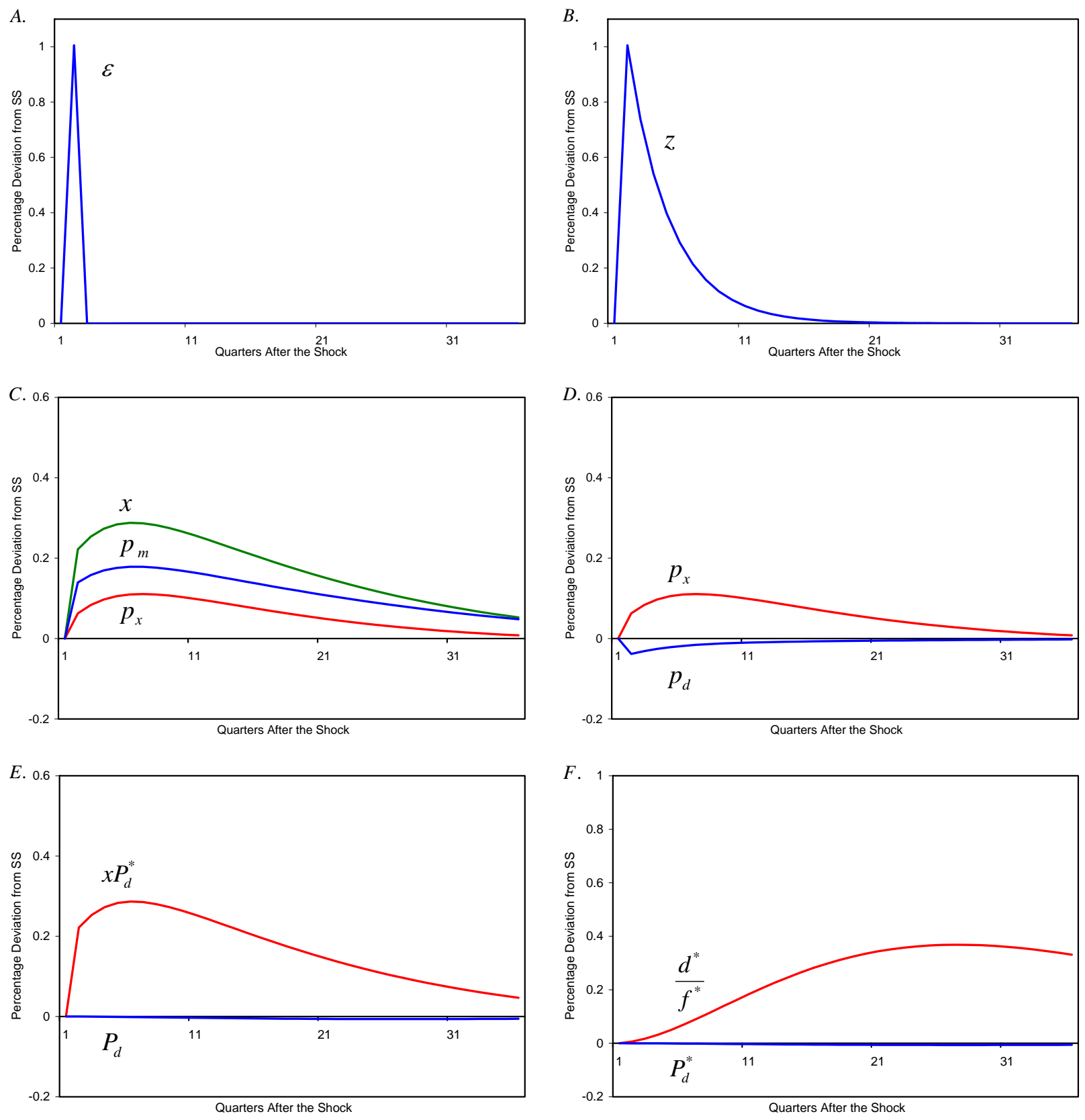

Figure 3: Benchmark model: Impulse response to a positive productivity shock in the domestic country. 

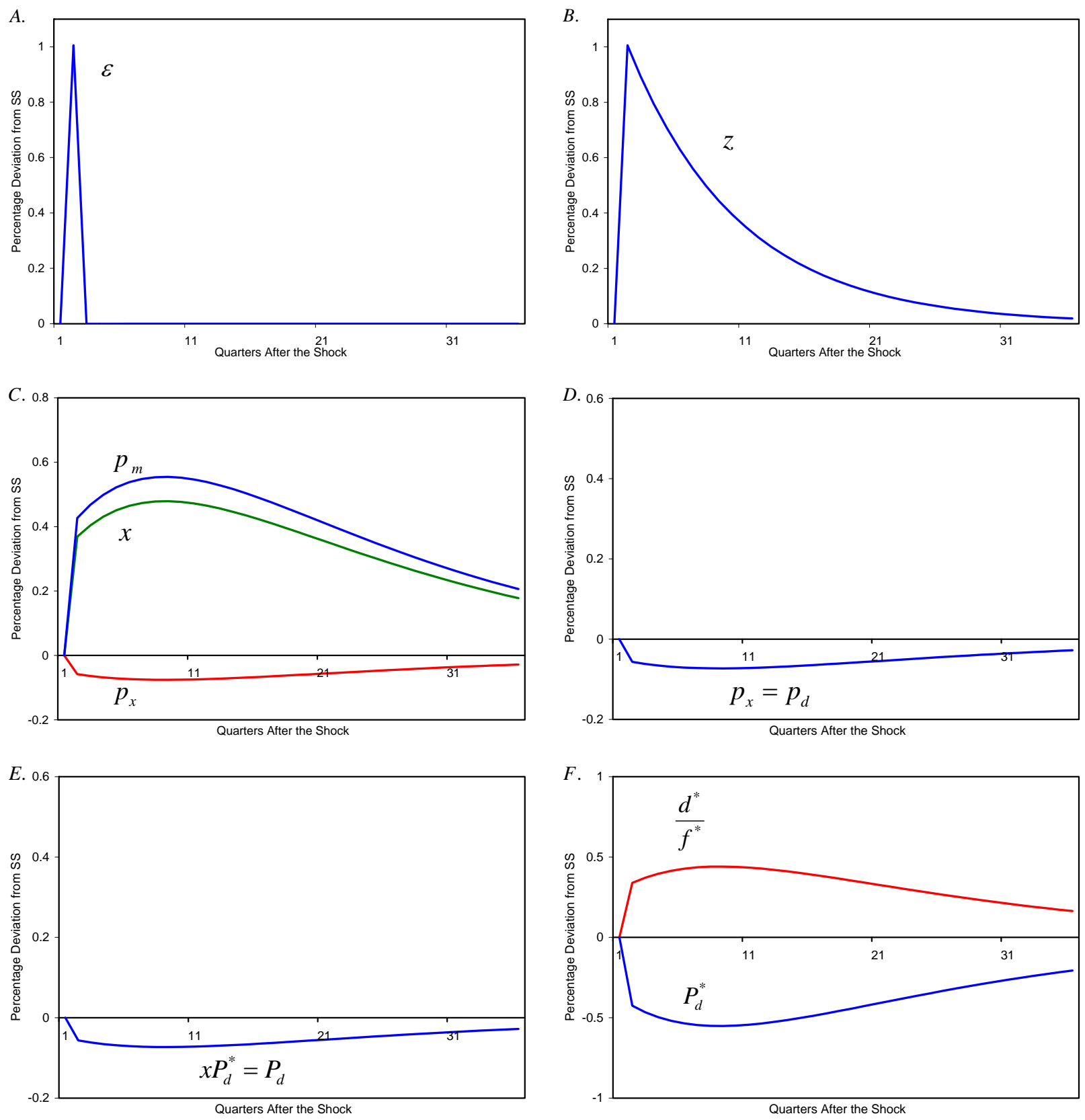

Figure 4: Standard model $(\gamma=0.7)$ : Impulse response to a positive productivity shock in the domestic country. 

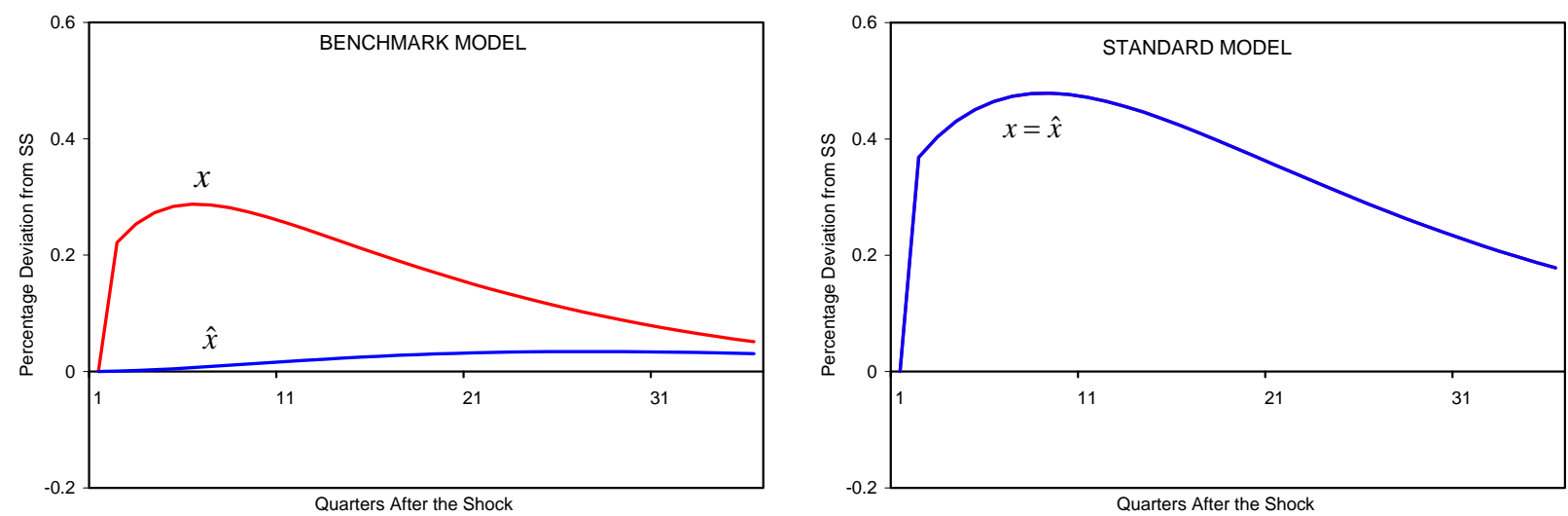

Figure 5: Benchmark model vs. standard model: Decomposition of the real exchange rate impulse response to a positive productivity shock in the domestic country. 